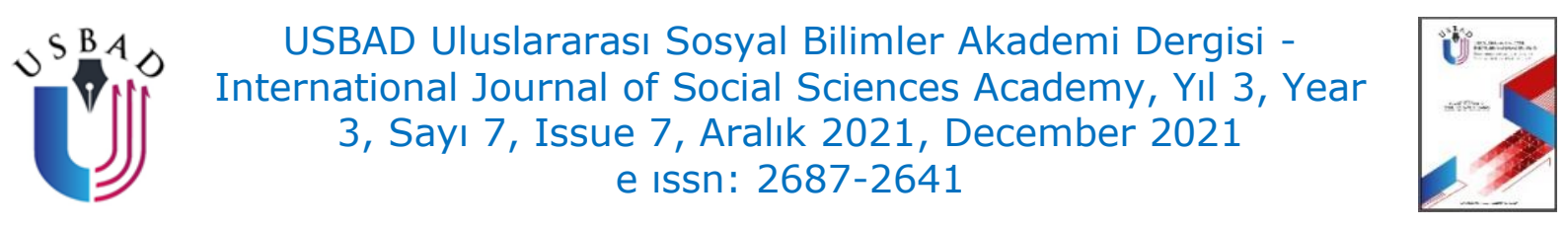

\title{
SOSYAL BİLGİLER ÖĞRETMENLERİ VE ÖĞRENCİ GÖRÜŞLERİNE GÖRE UZAKTAN EĞİTİM SÜRECİ*
}

DISTANCE EDUCATION PROCESS

ACCORDING TO THE OPINIONS OF SOCIAL STUDIES TEACHERS AND STUDENT

\section{Şengül KORKUT}

Bilim Uzm., Bolu Abant İzzet Baysal Üniversitesi, Lisansüstü Eğitim Enstitüsü, Bolu/Türkiye.

Science Exp., Bolu Abant İzzet Baysal University, Graduate School of Education Bolu/Turkey. sengulkrkt@gmail.com

ORCID ID: 0000-0002-5199-4653

\section{Hatice MEMIŞOĞLU}

Doç. Dr., Bolu Abant İzzet Baysal Üniversitesi, Eğitim Fakültesi, Bolu/Türkiye.

Associate Prof., Bolu Abant İzzet Baysal

University, Faculty of Education Bolu/Turkey. memisoglu_h@ibu.edu.tr ORCID ID: 0000-0003-3987-8454

\section{Makale bilgisi | Article Information DOI: $10.47994 /$ usbad.928916}

Makale Türü / Article Type: Araştırma Makalesi / Research Article Geliş Tarihi / Date Received: 27.05.2021

Kabul Tarihi / Date Accepted: 24.11.2021

Yayın Tarihi / Date Published: 20.12.2021

Yayın Sezonu / Pub Date Season: Aralık / December

Bu Makaleye Atıf İçin / To Cite This Article: Korkut, Ş. \& Memişoğlu, H. (2021). Sosyal Bilgiler Öğretmenleri ve Öğrencilerin Görüşlerine Göre Uzaktan Eğitim Süreci. USBAD Uluslararası Sosyal Bilimler Akademi Dergisi 3(7), 1639-1682.

Intihal: Bu makale intihal.net yazılımınca taranmıştır. İntihal tespit edilmemiştir.

Plagiarism: This article has been scanned by intihal.net. No plagiarism detected.

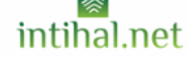

İletişim: Web: https://dergipark.org.tr/tr/pub/usbad mail: usbaddergi@gmail.com

\footnotetext{
* Bu çalışma 3. Uluslararası Sosyal Bilimler ve Eğitim Bilimleri Sempozyumu'nda (10-11 Nisan 2021) sözlü bildiri olarak sunulmuştur.
} 
Öz: Bu araştırmanın amacı, sosyal bilgiler öğretmenleri ve ilkokul-ortaokul öğrencilerinin uzaktan eğitim sürecine ilişkin görüşlerini belirlemektir. Uzaktan eğitime yönelik olumlu ve olumsuz görüşler ele alınmış, sorunlara yönelik çözüm önerileri tespit edilmeye çalışımıştır. Bu araştırmada nitel araştırma yöntemlerinden biri olan olgu bilim deseni kullanılmışır. Araştırmanın çalışma grubunu, farklı okullarda görev yapmakta olan 40 sosyal bilgiler öğretmeni ve 40 ilkokul ve ortaokul düzeyinde eğitim gören 4-7. sınıf öğrencileri oluşturmaktadır. Verilerin toplanmasında yarı yapılandırılmış görüşme formundan yararlanılmıştır. Araştırma verileri betimsel analiz tekniği ile çözümlenmiştir. Araştırma bulgularına göre, uzaktan eğitime ilişkin olumlu görüşlerden öne çıkanlar, uzaktan eğitimin faydalı, zengin içerikli, ilgi uyandıran, öğrenmeyi hızlandıran etkili bir sistem olduğudur. Uzaktan eğitime ilişkin öne çıkan olumsuz görüşler ise, teknolojik altyapı eksiklikleri, öğrencinin derslere katılımında yaşanan sorunlar, eğitim süresince ekran önünde olmaktan dolayı ortaya çıkan sağlık sorunları, akran öğrenme eksikliğidir. Uzaktan eğitimde yaşanan sorunların çözümlerine yönelik olarak, sosyal bilgiler öğretimi programının güncellenmesi ve uzaktan eğitime yönelik hizmet içi eğitimlerin düzenlenmesi gibi önerilerde bulunulmuştur.

Anahtar Kelimeler: Uzaktan Eğitim, Sosyal Bilgiler, Öğretmen, Öğrenci, Görüş

Abstract: The purpose of this research is to determine the views of social studies teachers and primary and secondary school students about the distance education process. Positive and negative views on distance education were discussed, and solution suggestions for problems were tried to be determined. In this study, the phenomenology design, which is one of the qualitative research methods, was used. The study group of the research consists of 40 social studies teachers working in different schools and 40 primary-secondary schools 4-7. students studying at the grade level. Semi-structured interview form is used in data collection. Descriptive analysis technique is used for the analysis of study data. Study findings reveal that distance education is useful and effective system having a rich content, arousing interest, and accelerating learning, which are some of the significant positive opinions regarding distance education. Some of the significant negative opinions related to distance education, on the other hand, are technological infrastructure deficiencies, problems experienced during the students' participation in lessons, health problems occurring due to staying in front of the screen during education, and peer learning deficiencies. In terms of solving the problems experienced in distance education, some suggestions such as updating the social studies education program and regulating the in-service training for distance education are made.

Key Words: Distance Education, Social Studies, Teacher, Student, Opinion GíRìs

Küresel boyutta yayılan Covid-19 salgınından korunmak için alınan önlemler nedeniyle dünyanın birçok ülkesinde yüz yüze eğitime ara verilerek, uzaktan eğitime geçilmiştir (Yamamato ve Altun, 2020). 
Salgından korunmak amacıyla 2019 yılında, dünyada yaklaşık 770 milyon öğrenci yüz yüze eğitime ara verme durumunda kalmıştır (Zhong, 2020). Uzaktan eğitimin tarihi bir geçmişi olmasına rağmen; küresel boyutta hızlı bir şekilde ivme kazanması uzaktan eğitimin öneminin tekrar fark edilmesini sağlamıştır (Fourie, 2001).

Uzaktan eğitim, zaman ve mekân açısından farklı ortamlarda bulunan öğretmen ve öğrenciler arasında oluşan eğitim-öğretim faaliyetlerinin tümü olarak tanımlanmaktadır (Yalın, 2008). Uzaktan eğitim faaliyetleri, mektupla başlayan yolculuğuna günümüzde bilgisayar, tablet, telefon, yazılım programları, medya havuzları ve internet aracılığıyla, çevrim içi ve çevrim dışı olarak sesli, görüntülü, konuşarak, yazarak yapılmaktadır. Bu faaliyetler, aynı anda canlı diyaloglar ve etkileşimlerle olabileceği gibi çeşitli kayıtlardan da yapılmaktadır. Uzaktan eğitim öğreticileri ve öğrenenleri çeşitli eğitimlere ihtiyaç duyulduğunda daha önce yapılmış olan kayıtlardan yararlanabilmektedir. Teknolojinin hızla gelişmesi, uzaktan eğitim modellerinin de sürekli olarak gelişim ve değişim göstermesini de beraberinde getirdiği söylenebilir. Mclendon (1999) tarafından uzaktan eğitim, mektupla eğitim, çoklu ortam modeli, tele öğrenme modeli, esnek öğrenme modeli olarak gruplandırılmıştır (Kırık, 2016).

Uzaktan eğitim terimi ilk olarak, 1892 yılında Wisconsin Sayfa | 1641 Üniversitesi'nin kataloğunda William Lighty'in 1906 yazdığı bir yazısında "Distance Education" kullanılmıştır (Kaya, 2002). İngiltere'de Londra Üniversitesi'nde uzaktan eğitim, mektupla öğretim olarak başlamıştır. 1830 yılında üniversiteyi dışarıdan bitirmek isteyen öğrenciler için geliştirilmiş mektupla eğitim sistemi daha sonra telefon, bilgisayar ve videolar ile yoğun olarak kullanılmıştır. 1969 yıllında İngiltere'de kurulan Açık Üniversite'de örgün eğitimde yükseköğretime devam edemeyenler için ilk kurumsal yetişkin eğitim programları oluşturulmuş ve uzaktan eğitimle öğretim yapılmıştır (Gülbahar, 2008).

Gelişmeler doğrultusunda 1971 yılında lisans eğitimi vermeye başlayan bu üniversitede iletişim teknolojileri de yaygın olarak kullanılmıştır. Bu üniversitenin uzaktan eğitim uygulamaları birçok ülkeye model oluşturmuştur. Bu uygulamaları kendi uzaktan eğitim sistemlerine uyarlamış olan ülkeler arasında Çin, Kosta Rika, İran, Japonya, Malezya, Nijerya, Polonya, İspanya, Sri Lanka, Tayvan ve Tayland vardır (İşman, 2011).

Türkiye' de uzaktan eğitim ilk olarak 1927 yılında bir toplantıda dile getirilmiştir. Ancak herhangi bir uygulamada kullanılmamıştır. Dewey tarafından yazışarak/mektupla öğrenmenin öğretmen eğitiminde 
kullanılabileceğini önermiştir. Gezgin kütüphanelerin kurulması fikri de bu öneriler arasında çok ilgi çekmiştir (Bozkurt, 2017). 1956 yılında Ankara Üniversitesi Hukuk Fakültesi Banka ve Ticaret Hukuku Araştırma Enstitüsü'nde uzaktan eğitim uygulamalarına başlanmıştır. Bir banka çalışanlarına hizmet içi eğitimlerde mektupla uzaktan eğitim uygulaması yapmıştır. 1958 yılında ise Türk eğitim sisteminde uzaktan eğitim uygulamasında Türkiye Cumhuriyeti Millî Eğitim Bakanlığı bünyesinde "Mektupla Öğretim Merkezi" kurulmuş ve bu merkez dışarıdan okul bitirmek isteyenlere hazırlık kurslarını mektupla vermiştir (Çallı vd., 2002). 1974 yılında kurulan Mektupla Öğretim Merkezi, Mektupla Öğretim Okulu'na dönüştürülmüş ve 1983 yılında Mesleki ve Teknik Açık Öğretim Okulu adını almıştır. Uzaktan eğitim vermek üzere 1981 yılında yürürlüğe giren bir yasa ile Anadolu Üniversitesi bünyesinde kendi küllerinden doğan bir Açık Öğretim Fakültesi kurulmuştur (Emre, 2002). 2000 yıllarında bilgisayar kullanımı gitgide artınca internete olan talep de artmış hatta ihtiyaç haline gelmiştir (Göktaş ve Kayri, 2005).

Her türlü bilgiye ulaşımı kolaylaştıran ve yaklaştıran bilgisayar sistemleri ve internet ağı, dünyadaki gelişmelerle ilgili haberlere anında ulaşımı sağladığı gibi, kültür ve sanattaki değişimler, siyasi ve ekonomik gelişmeler, bankacılık ve finans, eğitim ve sağlık işleri gibi birçok Sayfa | 1642 uygulamayı kullanıcılarına sunmaya başlamıştır (Horzum, 2010; Bozkurt, 2017). Teknolojik devrim niteliğindeki internet ve sosyal medya ağlarını kullanımı insan hayatının önemli bir parçası haline gelmiştir. 1960'ların sonlarından itibaren uzaktan eğitim bir bilim olarak algılanmaya başlamış ve alanında kuramlar oluşturulmaya başlanmıştır (Garrison, 2000).

Uzaktan eğitimdeki "uzaklık" terimini sorgulamaya yönelik çalışmalar yapan Dewey (1949) ve Moore (1973), bunun "yanlış anlama ve psikolojik boşluğa yol açan uzaklık" olduğunu belirterek, transaksiyon kuramı ile temellendirilmiştir (akt. Horzum, 2011). Başka bir ifadeyle; uzaktan eğitimde, öğrenci ve öğretmen arasında bir mesafe oluştuğu ve bu mesafenin sadece coğrafi olmadığını, eğitsel ve psikolojik yönden de bir uzaklık olduğunu öne sürülmüş ve bu uzaklığın yarattığı boşluğu transaksiyonel uzaklık olarak tanımlanabileceğini savunulmuştur (Moore ve Kearsley, 2011).

Uzaktan eğitimde karşılıklı etkileşim söz konusudur. Etkileşimi asgari iki varlık ve bu iki varlığın karşılıklı yarattıkları olaylar bütünü olarak tanımlanmıştır (Wagner, 1994'dan akt. Saykılı, 2019). Öğrencilerin ruhsal yapılarındaki değişimleri sağlayabilmesi, bilgiyi edinmede öz düzenleme yapabilmesi ve elde ettiği bilgileri kendi bilgileri ile birleştirerek yeniden 
düzenleyebilmesi için, içerik ile etkileşimde olmaları gerekmektedir. Öğrenci-içerik etkileşimi, öğrencilerin neyi, nasıl, niçin öğreneceklerine karar verdikleri öğrenme içeriklerini incelemeleri ve bu içerikle çalışmaları neticesinde ortaya çıkan etkileşim türüdür. Öğretmenlerin öğretim planlamalarında öğretecekleri konu içeriklerine hakim olmaları önceden hazırlık yapmaları ve bu içerikleri gerektiren ögeler arasında etkileşim düzeylerini kestirebilmeleri ve etkileşim türlerini daha önceden iyice bilmeleri uzaktan öğrenme ortamının öğrencilere ulaşmasında üst düzey eğitim açısından önemlidir (Karataş vd., 2009). Uzaktan eğitimde etkileşimi sağlayan unsurlar; öğrencilerin iletişimini teşvik etmek; karşılıklılık ve işbirliğini geliştirmek; aktif öğrenmeyle meşgul olma, hızlı geri bildirim sağlamak, bir göreve ayrılan zaman miktarını vurgulamak, yüksek beklentileri aktarmak ve çeşitliliğe saygı duymaktır (Thurmond ve Wambach, 2003).

Uzaktan eğitimde diyalog öğretmen ve öğrenci arasında geçen bir etkileşim türüdür. Uzaktan eğitimlerde merkezde öğretmen değil, öğrenci olmalıdır. Öğrenci ne kadar merkezden uzaklaşırsa diyalogdan kopar ve etkileşimde bulunduğu eğitim ortamıyla transaksiyonel uzaklığı o kadar artar (Moore, 1993). Diyalog, karşılıklı bir şekilde öğrencilerin kavram ve kuramlarla alakalı sorunların ve zıtlıkların farkında olmasını da içerir (Evans Sayfa | 1643 ve Nation, 1989). Diyalogların eğitime ilişkin hedefi, öğrencilerdeki kavrama gücünü geliştirmektir (Gorsky vd., 2007).

Sosyal Bilgiler Dersi Öğretim Programı yapılandırıırken, dünyada yaşanan değişim ve gelişimler, mevcut programların değerlendirmelerine ilişkin sonuçlar ve intiyaç analizleri dikkate alınmaktadır (MEB, 2004). Sosyal Bilgiler dersinde uzaktan eğitim sürecinde oluşabilecek birçok gelişime ayak uydurmak, yenilikçi ve yapılandırmacı bir yaklaşımla öğretim programını tasarlamak, planlamak ve uygulamak öncelikleri arasında yer almaktadır. Son yıllarda dünyada ve Türkiye'de Sosyal Bilgiler öğretiminde teknoloji kullanımı hızla ilerlemektedir. Özellikle eğitim-öğretim süreçlerinin içinde ve sosyal bilgiler dersi öğretim uygulamalarında teknolojinin kullanılması, eğitim ve öğretimin devam etmesi açısından önemlidir (Yaylak, 2010).

Sosyal bilgilerde uzaktan eğitimde öğrencilerin ve öğretmenlerin intiyaç duyacağı yazılımlar, donanımlar, öğrencide ve öğretmende aranan nitelikler gibi birçok ayrıntılı araştırma yapılmaya devam etmektedir Uzaktan eğitimde etkileşim ve diyalog alanında açık öğretimde (Horzum, 2010), çevrimiçi uzaktan eğitimde öğretici yeterliliklerinde (Kavrat, 2013), uzaktan eğitim ve tanımı hususunda (Özdil, 1986; İnan, 2010), uzaktan 
eğitimin amaçlarına yönelik (Yenal, 2009), uzaktan eğitimde kullanılan eş zamanlı sanal sınıf araçlarının karşılaştırımasında (Çınar vd., 2011), uzaktan eğitime ilişkin öğretmen görüşleri üzerine (Parmaksız ve Sıcak, 2015; Erbil ve Kocabaş, 2019; Fidan, 2020; Alper, 2020; Arslan ve Şumuer, 2020; Dilekçi ve Limon, 2020; Adıgüzel, 2020; Demir ve Özdaş, 2020; Kurnaz vd., 2020 ; Türker ve Dündar, 2020; Mengi ve Alpdoğan, 2020; Özgül vd., 2020; Ünal ve Bulunuz, 2020; Gören vd., 2020); velilerin uzakta eğitime ilişkin görüşleri (Erol ve Erol, 2020; İnci Kuzu, 2020; Yılmaz vd., 2020); öğretmen adaylarının görüşlerine ilişkin olarak (Arslan, 2020; Gürel ve $\mathrm{Er}, 2020$; Duman, 2020); okul müdürlerinin görüşlerine yönelik (Keleş vd., 2020; Turan, 2020); öğretmenlerin mesleki gelişimlerinde bilgi ve iletişim teknolojilerinde (Odabaşı, 2003), uzaktan eğitimin öğrencilerin akademik başarısına etkisi üzerine (Karaman ve Akgül, 2015; Çoruk ve Çakır, 2017; Türker ve Yaylak, 2019), paydaş görüşleri (Özdoğan ve Berkant, 2020); eğitimde yeni iletişim teknolojileri internet üzerine (Karasar, 2004) alanyazında araştırmalar yapılmıştır. Görüldüğü gibi; uzaktan eğitimin uygulanmaya başlaması ile son yıllarda bu alanda yapılan araştırmalar artmıştır. Ancak, Sosyal Bilgiler öğretmenleri ve ilkokulortaokul öğrencilerin uzaktan eğitime ilişkin görüşlerini içeren çalışmalar az sayıdadır. Sosyal bilgiler öğretmenleri ve ilkokul-ortaokul öğrencilerinin uzaktan eğitime ilişkin görüşleri ile, Sosyal bilgiler dersinde online eğitim sürecinin eksiklerinin giderilmesine, sorunların tespit edilmesine ve çözümüne katkı sağlanabileceği düşünülmüştür.

Bu araştırmanın amacı, günümüzde uygulanmakta olan uzaktan sosyal bilgiler öğretiminde, öğretmenleri, ilkokul ve ortaokul öğrencilerinin karşılaştıkları sorunları ve bu sorunlara yönelik çözüm önerilerini belirleyebilmektir. Araştırmanın alt problemleri aşağıda sunulmuştur:

\section{Alt Problemleri}

1. Sosyal bilgiler öğretmenlerinin;

1.1. Uzaktan eğitime bakış açılarına yönelik görüşleri nelerdir?

1.2. Uzaktan eğitimde hazırlık ve uygulama sürecinde dikkat ettikleri hususlara ilişkin görüşleri nelerdir?

1.3. Sosyal bilgiler dersi açısından uzaktan eğitimde olumlu buldukları yönlere ilişkin görüşleri nelerdir?

1.4. Sosyal bilgiler dersi açısından uzaktan eğitimde karşılaşılan sorunlara ilişkin görüşleri nelerdir? (Öğrenci, sistem, okul yönetimi, uygulama, materyal, ders işlenişi).

1.5. Sosyal bilgiler dersi açısından uzaktan eğitimde karşılaşılan sorunlara yönelik önerilere nelerdir? 
1.6. Sosyal bilgiler dersinde etkili bir uzaktan öğretimde olması gereken özelliklere yönelik görüşleri nelerdir?

2. İlkokul ve ortaokul öğrencilerinin;

2.1. Sosyal bilgiler dersi açısından uzaktan eğitimde olumlu bulduğu yönlere ilişkin görüşleri nelerdir?

2.2. Sosyal bilgiler dersi açısından uzaktan eğitimde olumsuz bulduğu yönlere ilişkin görüşleri nelerdir?

2.3. Sosyal bilgiler dersi açısından nasıl bir uzaktan eğitim olması gerektiğine yönelik görüşleri nelerdir?

\section{YÖNTEM}

\subsection{Araştırmanın Modeli}

$\mathrm{Bu}$ araştırmada nitel araştırma desenlerinden biri olan olgu bilim (fenomenoloji) deseni kullanılmıştır. Olgu bilim deseni farkında olduğumuz ancak derinlemesine ve ayrıntılı bir anlayışa sahip olmadığımız olgulara odaklanmaktadır. Olgular, yaşadığımız dünyada olaylar, deneyimler, algılar, yönelimler, kavramlar ve durumlar gibi çeşitli şekillerde karşımıza çıkabilmektedir. Bize tamamen yabancı olmayan, aynı zamanda da tam olarak kavrayamadığımız olguları araştırmayı amaçlayan çalışmalar için olgu bilim uygun bir araştırma zemini oluşturur (Yıldırım ve Şimşek, 2011; Sayfa | 1645 Creswell, 2013). Sosyal bilgiler öğretmenleri ve ilkokul-ortaokul öğrencilerinin uzaktan eğitime ilişkin deneyimlerini ortaya çıkarmak, yaşanmış deneyimler sonucunda uzaktan eğitimin nasıl anlamlandırıldığını ortaya koymak için araştırmada olgu bilim deseni kullanılmıştır.

\section{2. Çalışma Grubu}

Araştırmanın çalışma grubunu, Malatya merkez ilçede farklı okullarda görev yapmakta olan 40 sosyal bilgiler öğretmeni ve 40 ilkokul-ortaokul düzeyinde öğrenim gören 4-7. sınıf öğrencileri oluşturmaktadır. Çalışma, 2020-2021 eğitim-öğretim yılında uygulanmıştır. Kolay ulaşılabilir örnekleme yöntemi çoğu zaman araştırmacının diğer örnekleme yöntemlerini kullanma olanağı bulamadığı durumlarda ve araştırmacıya hız ve pratiklik sağlama amacıyla kullanılmaktadır (Yıldırım ve Şimşek, 2011). Araştırmaya katılan öğretmenlere ait demografik bilgiler Tablo 1'de gösterilmiştir.

Tablo 1: Sosyal Bilgiler Öğretmenlere Ait Demografik Özellikler

\begin{tabular}{llclll}
\hline Cinsiyet & $\mathbf{n}$ & $\mathbf{\%}$ & Mezun Olunan Üniversite & $\mathbf{n}$ & \% \\
\hline Kadın & 20 & 50 & İnönü Üniversitesi & 5 & 12.5 \\
Erkek & 20 & 50 & Balıkesir Üniversitesi & 4 & 10 \\
Kıdem & & & Afyon Kocatepe Üniversitesi & 4 & 10
\end{tabular}


Şengül Korkut - Hatice Memişoğlu

\begin{tabular}{lrrlll}
$1-5$ yıl & 5 & 12.5 & Trakya Üniversitesi & 3 & 7.5 \\
$6-10$ yıl & 10 & 25 & Atatürk Üniversitesi & 3 & 7.5 \\
$11-15$ yıl & 5 & 12.5 & Marmara Üniversitesi & 3 & 7.5 \\
$16-20$ yıl & 6 & 15 & Anadolu Üniversitesi & 3 & 7.5 \\
21 yıl ve üstü & 14 & 35 & Giresun Üniversitesi & 2 & 5 \\
& & & İstanbul Üniversitesi & 2 & 5 \\
& & & Bolu Abant İzzet Baysal Üni. & 1 & 2.5 \\
& & Ahi Evran Üniversitesi & 1 & 2.5 \\
& & Akdeniz Üniversitesi & 1 & 2.5 \\
& & Aydın Adnan Menderes Üni. & 1 & 2.5 \\
& & & Celal Bayar Üniversitesi & 1 & 2.5 \\
& & & 18 Mart Üniversitesi & 1 & 2.5 \\
& & & Osmangazi Üniversitesi & 1 & 2.5 \\
& & Gazi Üniversitesi & 1 & 2.5 \\
& & KTÜ Üniversitesi & 1 & 2.5 \\
& & & Yüzüncü Yıl Üniversitesi & 1 & 2.5 \\
& & & Toplam & 40 & 100 \\
\hline
\end{tabular}

Tablo 1'de görüldüğü gibi; araştırmaya 40 Sosyal Bilgiler öğretmeni katılmıştır. Sosyal Bilgiler öğretmenlerinin 20'si kadın 20'si de erkektir. Araştırmaya katılan 40 öğretmenin 14'ü 21 yıl ve üstü öğretmenlik kıdeme sahiptir. Bu öğretmenlerden 10'u 6-10 yıl arasında bir sürede çalışan, 6'sı 16-20 yıl arasında 5'i 16-20 yıl ve 5 öğretmen de 1-5 yılları arasında kıdeme sahip sosyal bilgiler öğretmenleridir.

Sosyal bilgiler öğretmenlerinin 19 farklı üniversiteden mezun oldukları görülmektedir. İnönü Üniversitesinden 5, Balıkesir Üniversitesinden 4, Afyon Kocatepe Üniversitesinden 4, Trakya Üniversitesinden 3, Atatürk Üniversitesinden 3, Marmara Üniversitesinden 3, İstanbul Üniversitesinden 2, Giresun Üniversitesinden 2, Anadolu Üniversitesinden 3 mezun öğretmen bulunmaktadır. Tabloda görülen diğer üniversitelerden mezun olan 1'er sosyal bilgiler öğretmeni araştırmaya gönüllü olarak katılmışlardır. Araştırmaya katılan ilkokul ve ortaokul öğrencilere ait demografik bilgiler Tablo 2'de gösterilmiştir.

Tablo 2: İlkokul ve Ortaokul öğrencilerin devam ettikleri sınıf seviyelerine göre dağılımı

\begin{tabular}{lcl}
\hline Sınıf & $\mathrm{N}$ & $\%$ \\
\hline 4.Sınıf & 16 & 40 \\
5.Sınıf & 9 & 22.5 \\
6.Sınıf & 8 & 20 \\
7.Sınıf & 7 & 17.5 \\
& & \\
Toplam & 40 & 100 \\
\hline
\end{tabular}


Tablo 2'de özel ve devlet okullarına devam eden öğrencilerin 16'sı ilkokul 4. sınıf, 24'ü ise ortaokul 5-6-7 sınıf düzeyinde öğrenim gören öğrencilerdir. Bu öğrenciler bu araştırmaya gönüllü olarak katılmışlardır.

\subsection{Verilerin Toplanması}

Veri toplama aracı olarak, araştırmacılar tarafından oluşturulan yarı yapılandırılmış görüşme formları kullanılmıştır. Taslak araştırma soruları için uzaktan eğitim üzerine çalışmalar yapılmıştır. Veri toplama araçlarının oluşturulması aşamasında; öncelikle literatür taraması yapılmıştır. Literatür taramasından sonra araştırma soruları oluşturulmuş ve 3 alan uzmanının görüşleri alınmıştır. Pilot uygulama yapıldıktan sonra yarı yapılandırılmış görüşme formuna son şekli verilmiştir. Görüşme için oluşturulan veri toplama formları Google Formlar web uygulaması aracılığıyla paylaşılarak katılımcılara e-posta yoluyla gönderilmiştir.

\subsection{Verilerin Analizi}

Araştırma verileri betimsel analiz tekniği ile çözümlenmiştir. Yıldırım ve Şimşek (2011)'e göre; betimsel analiz önceden belirlenmiş bir çerçeveye bağlı olarak nitel verilerin işlenmesi bulguların tanımlanması, tanımlanan bulguların yorumlanması adımlarını içermektedir. Walcott (1994)'a göre ise, verilerin özgün formuna bağlı kalarak doğrudan alıntılarla ve betimsel bir Sayfa | 1647 yaklaşımla okuyucuya sunulmasıdır. Betimsel analiz tekniğinde elde edilen veriler okuyucuya özetlenmiş ve yorumlanmış olarak sunulmuştur. Betimsel analiz yönteminde veriler analizi dört aşamada gerçekleştirilir. Öncelikli olarak bir çerçeve oluşturulur, çerçeveye göre veriler işlenir, bulgular tanımlanır ve bulgulardan elde edilen veriler, daha önceden belirlenen başlıklar altında özetlenir ve yorumlanır (Altunışık vd., 2010). Araştırmada toplanan veriler, görüşme formlarından doğrudan alıntılar yapılmış ve okuyucuya betimsel bir yaklaşımla, belirlenen temalar ve temalar arası ilişkilerle ortaya konulmaya çalışılmıştır. Elde edilen görüşler tablo haline getirilmiş ve alıntılar sunulmuştur. Tema ve içerik uyumu her iki yazar tarafından da kontrol edilmiştir. Görüşme verilerinin analizinin güvenirliği için Miles ve Huberman (2015) tarafından geliştirilen güvenirlik formülü [Güvenirlik=Görüş birliği sayısı / (Toplam görüş birliği + Görüş ayrılığı sayısı)] kullanılmıştır. Güvenirlik formülü sonucunda, güvenirlik=.90 bulunmuştur. 


\section{BULGULAR}

\subsection{Birinci Alt Probleme İlişkin Bulgular}

Sosyal bilgiler öğretmenlerinin uzaktan eğitime bakış açıları, olumlu buldukları yönler, sorunlar ve çözüm önerilerine ilişkin bulgular tablo haline getirilerek, alıntılarla gösterilmiştir.

\subsubsection{Sosyal Bilgiler Öğretmenlerine Uzaktan Eğitime Yönelik Bakış Açılarına İlişkin Bulgular}

Araştırmaya katılan sosyal bilgiler öğretmenlerine uzaktan eğitime yönelik bakış açılarına ilişkin görüşleri Tablo 3' te gösterilmiştir.

Tablo 3: Sosyal Bilgiler Öğretmenlerinin Uzaktan Eğitime Bakış Açısına İlişkin Görüşleri

\begin{tabular}{|c|c|c|c|c|c|c|}
\hline \multirow[t]{2}{*}{ Görüşler } & \multicolumn{6}{|c|}{ Kıdem } \\
\hline & $1-5$ & $6-10$ & 11-15 & $16-20$ & $21+$ & T.G. \\
\hline $\begin{array}{l}\text { Uzaktan eğitimi olumlu } \\
\text { buluyorum (rahat, tasarruflu, } \\
\text { zengin içerikli, güvenli, kolay). }\end{array}$ & 13 & 12 & 14 & 11 & 11 & 61 \\
\hline $\begin{array}{l}\text { Uzaktan eğitimi olumsuz } \\
\text { buluyorum (altyapı eksik, } \\
\text { sağlıksız, asosyal) }\end{array}$ & 4 & 6 & 5 & 5 & 7 & 27 \\
\hline
\end{tabular}

Yıllara Göre Toplam Görüş

$17 \quad 18$

19

$16 \quad 18$

88

Sayfa | 1648

Tablo 3'te, olumlu görüşlerin kıdem yılına göre dağılımı incelendiğinde 11-15 yıllık öğretmenler en fazla olumlu görüş bildiren grup olduğu görülmektedir. Öğretmenler olumlu bakış açısına sebep olarak, uzaktan eğitimin yüz yüze eğitimin yapılamadığı zamanlarda kullanılacak en iyi sistem olduğunu belirtmektedirler.

Uzaktan eğitime yönelik olumlu görüşlerden bazıları şu şekildedir: Uzaktan eğitim, yüz yüze eğitimden daha kaliteli ve hızlı gerçekleşiyor çünkü zengin içeriklerle eğlenceli bir şekilde yapıllyor. Öğrenciler işitsel, görsel ve yazılı kaynaklardan oldukça iyi bir şekilde yararlanıyorlar. Öğretimin kalitesinde artış olduğunu düşünüyorum (Ö.11). Uzaktan eğitim yüz yüze eğitimlerin uygulanamayacağı her yerde kolaylıkla uygulanabilecek en iyi eğitim sistemidir (Ö. 14). Öğrenciler dikkatli dinlemek zorunda kalıyorlar. Söz hakkı almada sıkıntı olmuyor. Öğretmen iyi yönetirse bu durum yüz yüze eğitimden daha adaletli (Ö.12). Evde ders yapılması çok rahatlatıcı. Sabah erken kalkıp gitmiyoruz, okula gitmeden eğitim vermek çok büyük kolaylık (Ö.33). Uzaktan Eğitim zengin içeriklerle öğrencinin merakını arttırıyor, ilgisini çekiyor (Ö.9).

Uzaktan eğitime yönelik olumsuz görüşlerden bazıları şu şekildedir: Uzaktan eğitime ilişkin olumlu herhangi bir düşüncem bulunmamaktadır. 
Eğitimi ilerletici değil, duraksatıcı veya geriletici özelliğe sahip. Yüz yüze gibi bir olumlu etkisi olmadı maalesef. Yüz yüze eğitimin yerini tutmuyor. Yok, hiçbir olumlu yönü yok (Ö.4). Altyapı eksikliği ve sıkıntılar motivasyonumu düşürüyor. Bu durum öğrenciyi de olumsuz etkiliyor (Ö.7). Uzaktan eğitimde kullanılan teknolojik bilgiler, metotlar, teknikler konusun da benim gibi öğrencilerim de velilerim de sıkıntılar yaşıyorlar (Ö.34). Öğrenciler sosyalleşme sıkıntıları yaşıyorlar ve bizler de bireysel başarılar üzerinde doyum sağlamaya çalışıyoruz. Çocuklar evde yalnız oldukları için mutsuz olduklarını sık sık ifade ediyorlar bana (Ö.17). Öğrencileri derse katmakta zorluk çekiyorum. Öğrenci motivasyonları sık sık düşüyor, dikkat çekme de sıkıntı yaşıyorum (Ö.29). Uzaktan eğitim benim de öğrencilerimin de sağığını bozuyor. Sürekli ekran karşısında olunca omurgada, sinir sisteminde ve gözlerde bozukluk ilerliyor (Ö.5). Öğrencilerimden birisi migren atakları geçirmeye başladı, beyaz ışıklı ekrana bakamıyor, 3'ü oyunlara bağımlılık göstermeye başladı, 4 öğrencim ekrana bakarak ders işlenmesine karşı sürekli direnç gösteriyor, derslere katılmakta sıkıntıları var (Ö.28).

\subsubsection{Sosyal Bilgiler Öğretmenlerinin Uzaktan Eğitimde Hazırlık ve Uygulama Sürecinde Dikkat Edilen Hususlara İlişkin Bulgular}

Sosyal bilgiler öğretmenlerinin uzaktan eğitimde hazırlık ve uygulama sürecinde özellikle dikkat edilen hususlara ilişkin görüşler gruplanarak Tablo 4 'te sunulmuştur.

Tablo 4: Sosyal Bilgiler Öğretmenlerinin Uzaktan Eğitimde Hazırlık ve Uygulama Sürecinde Dikkat Edilen Hususlara İlişkin Görüşleri

\begin{tabular}{c|c|c|c|c|c|c|c}
\hline \multicolumn{1}{c}{ Görüşler } & \multicolumn{9}{c}{ Kıdem } \\
& $\mathbf{1 - 5}$ & $\mathbf{6 - 1 0}$ & $\mathbf{1 1 - 1 5}$ & $\mathbf{1 6 - 2 0}$ & $\mathbf{2 1 +}$ & \multicolumn{2}{c}{ T.G. } \\
\hline Öğretimi planlama hazırlığı & 2 & 3 & 3 & 4 & 7 & 19 \\
Dijital eğitim havuzu hazırlığı & 1 & 2 & 2 & 4 & 6 & 15 \\
Teknolojik altyapı hazırlığı & 1 & 1 & 2 & 3 & 5 & 12 \\
Müfredata ve sınıf düzeyine & 1 & 1 & 2 & 2 & 5 & 11 \\
göre hazırlık & 1 & 1 & 1 & 3 & 4 & 10 \\
Yöntem teknik hazırlığı & 1 & 2 & 1 & 2 & 4 & 10 \\
Motivasyon ve güdüleme h. & 1 & 1 & 1 & 2 & 4 & 9 \\
Değerlendirme hazırlığı & & & & & & \\
\hline Toplam Görüş & $\mathbf{8}$ & $\mathbf{1 1}$ & $\mathbf{1 2}$ & $\mathbf{2 0}$ & $\mathbf{3 5}$ & $\mathbf{8 6}$ \\
\hline
\end{tabular}

Tablo 4 incelendiğinde, Sosyal bilgiler öğretmenleri uzaktan eğitimde hazırlık ve uygulama sürecinde, işlenecek dersi ve konuyu öncelikli olarak planladıklarını (19), dijital medya havuzu hazırlığı yaptıklarını (15), 
teknolojik alt yapı yeterliliği için ön hazırlık ve kontrolleri her gün yaptıklarını (12) belirtmişlerdir. Öğretmenler derse başlamadan evvel planlama, dijital eğitim havuzu hazırlığı, teknolojik altyapı hazırlığı, müfredata ve sınıf düzeyine göre ders konularının hazırlığı, derste kullanılacak yöntem ve teknik hazırlığı, öğrenci motivasyonu ve güdüleme hazırlığı, işlenilen konuların öğrenilip öğrenilmediğine dair değerlendirme hazırlığı yaptıklarını ifade etmişlerdir. Öğretmenlerin uzaktan eğitimde hazırlık ve uygulama sürecinde özellikle dikkat edilen hususlardan öncelikli olanlar; zamanı doğru kullanma, teknolojik altyapı ve eğitim materyali hazırlığı ve öğrencinin derse katılımı olduğu belirlenmiştir. Bunlara sebep olarak uzaktan eğitimin altyapı sağlayıcılarının, medya havuzlarının, eğitimsel dokümanlarının ve katılımcı öğrencilerin olması gerektiği ifade edilmiştir. Sosyal bilgiler öğretmenlerinin uzaktan eğitimde hazırlık ve uygulama sürecinde özellikle dikkat edilen hususlara ilişkin görüşler şu şekildedir:

Öğretimi planlama: Zamanı doğru planlıyorum çünkü eğitim bir süreç işidir. Plansız ve zamansız eğitim olmaz (Ö.23). Önceden her şeyi planlıyorum ve süreyi doğru kullanıyorum (Ö.11).

Dijital eğitim havuzu hazırlığı: Derse hazırlık boyutunda medya havuzları, sunum ve slaytlar, animasyonlar, yazılı notlar, sınavlar, eğitim sürecinde kullanacak araç gereç ve dokümanları araştırıyorum ve hazırlıyorum çünkü eğitim sürecimde kullanmam gerekiyor (Ö.21). Sosyal Bilgiler öğretimine sanal müzeler, tarihi belge bilgi ve kanıtlara ulaşım çok çok iyi oldu özellikle bunlardan yararlanıyorum (Ö.16).

Teknolojik altyapı hazırlığı: ( $p c$, web, tablet, derse yönelik araç ve gereçler) Teknolojik altyapı hazırlığı yapıyorum çünkü uzaktan eğitimin olmazsa olmazlarıdır (Ö.40).

Müfredata ve sınıf düzeyine göre hazırlığı: Müfredata ve sınıf düzeyine uygun ders havuz hazırlığı yapıyorum çünkü müfredat dışı internet ortamında gezinmek dijital ortamın en büyük risklerindendir (Ö.33).

Motivasyon ve güdüleme hazırlığı: Derse katıımı arttırmak ve dikkat çekmek için esprili ders ortamları hazırlığı yapıyorum. Öğrencilere de hazırlık yaptırıyorum (Ö.27). Dersi ilgi çekici ve eğlenceli yapacak şekilde öğrencileri derse katarak işlemeye çalışıyorum bunun için ön hazırlık yapıyorum (Ö.2).

Yöntem teknik hazırlığı: Doğru yöntem ve teknik kullanmaya dikkat ediyorum çünkü doğru etkileşim ve diyalog öğrencinin isteği üzerinde için çok gerekli. Uygulama ağırlıklı çalışıyorum (Ö.35). 
Değerlendirme hazırlığı: Herkese eşit söz hakkı veriyorum. Adaletli olmak her insan için önemlidir. Uzaktan eğitimde çok iyi oluyor (Ö.8). Değerlendirme için öğrenci ve ödev takibi yapıyorum dijital değerlendirme araç ve gereçlerimi önceden konuya ve seviyeye uygun olarak hazırlamaya özen gösteriyorum (Ö.19).

\subsubsection{Sosyal Bilgiler Öğretmenlerinin Uzaktan Eğitime Yönelik Olarak Olumlu Buldukları Yönlere İlişkin Bulgular}

Sosyal bilgiler öğretmenlerinin uzaktan eğitime yönelik olarak olumlu buldukları yönlere ilişkin görüşleri Tablo 5 ' te gösterilmiştir.

Tablo 5: Sosyal Bilgiler Öğretmenlerinin Uzaktan Eğitime İlişkin Olumlu Görüşleri

\begin{tabular}{l|l|l|l|l|l|l|l}
\hline Görüşler & \multicolumn{9}{c}{ Kıdem } \\
& $\mathbf{1 - 5}$ & $\mathbf{6 - 1 0}$ & $\mathbf{1 1 - 1 5}$ & $\mathbf{1 6 - 2 0}$ & $\mathbf{2 1 +}$. G. \\
\hline Salgının yayılmasını engelleme & 1 & 2 & 1 & 2 & 3 & 9 \\
Zamandan kazanım sağlama & 1 & 2 & 1 & 2 & 2 & 8 \\
$\begin{array}{l}\text { Bilgiye erişim kolay ve zengin } \\
\text { içerik sunma }\end{array}$ & 1 & 2 & 1 & 2 & 2 & 8 \\
Evde, rahat ve güvenli olma & 1 & 2 & 1 & 1 & 2 & 7 \\
Ailelerin sürece aktif katılımını & 1 & 1 & 2 & 2 & 2 & 7 \\
sağlama & & & & & & \\
Öğrenciyi araştırmaya sevk etme & 1 & 1 & 1 & 1 & 1 & 6 \\
Eğlenceli ve ilgi çekici olması & 1 & 1 & 1 & 1 & 1 & 6 \\
Öğrenmeyi kalıcı hale getirmesi & 1 & 2 & 1 & 1 & 2 & 5 \\
Daha hızlı öğrenmeyi sağlama & 1 & 3 & 1 & 1 & 1 & 5 \\
Eşit söz hakkı oluşturma & 1 & 1 & 1 & 1 & 1 & 5 \\
\hline Toplam Görüş & $\mathbf{1 0}$ & $\mathbf{1 7}$ & $\mathbf{1 2}$ & $\mathbf{1 3}$ & $\mathbf{1 4}$ & $\mathbf{6 6}$ \\
\hline
\end{tabular}

Tablo 5'te görüldüğü gibi; Sosyal bilgiler öğretmenleri, uzaktan eğitim öğretim süreçlerinde kullanılması gerekli bir sistem olduğu, zamandan tasarruf sağladığı, öğrenmeyi kolaylaştırdığı, ilgi çektiği için motivasyonu arttırdığı yönünde görüş bildirmişlerdir. 40 öğretmenden 9'unun görüşü, uzaktan sosyal bilgiler öğretiminin gerekli olduğu yönündedir. Uzaktan eğitim zamandan kazanım sağlıyor, dijital bilgiye erişim kolay ve zengin içerik sunuyor, evde, rahat ve güvenli oluyor, aileler eğitim öğretim süreçlerine aktif katılım gösteriyorlar, öğrenciyi araştırmaya sevk ediyor, eğlenceli geçiyor, rahattır, dijital içerikler ilgiyi canlı tutuyor, öğrenciyi motive ediyor, eşit söz hakkı oluşturuyor görüşleri ifade edilmiştir. Öğretmenlerin 5 'inin görüşü, uzaktan eğitimin öğrencileri araştırmaya sevk ettiği yönündedir. Uzaktan eğitimle ilgili toplam 66 öğretmen görüşünün 7'sinde eğitimin evlerden sürdürülmesine olumlu bakılmaktadır. Ev ortamının rahatlığı ve güvenliği öğrencilerde daha iyi motivasyon sağladığı, 
öğrenmeyi daha kalıcı hale getirdiği ifade edilmiştir. Bu görüşlerden olumlu bulunanlardan bazıları aşağıda belirtilmiştir:

Uzaktan eğitim gereklidir. Hastalıktan koruyor: Yaşanılan süreçte yapılabilecek en doğru teknik budur. Öğrencilerin eğitim ihtiyaçlarını karşıladıkları bir sistemin olması iyi için en iyi çözüm uzaktan eğitimdir (Ö.25).

Eğitimde zamandan tasarruf sağlıyor: Zamandan ve maliyetten tasarrufu çok iyi (Ö.15). Pratik, zamandan tasarruflu, tüm dersler kolayca işlenebiliyor. Bilgi çok kolayca kontrol edilebiliyor (Ö.29).

Dijital bilgiye erişim kolay ve zengin içerik sunuyor: Çok avantajlı, dijital ortam zenginliği çocuklara sunulunca ders daha ilginç etkili oluyor. Harita ve diğer görselleri ekrandan daha net ve detaylı şekilde görebiliyorum Interneti daha etkili kullanabiliyoruz. İstediğimiz görsele, materyale daha kolay erişebiliyoruz. Dijital ortamdaki birçok materyal herhangi bir kısıtlama olmadan kullanılabiliyor (film, animasyon, harita vb.) (Ö.25).

Öğrenciler evde rahat ve güvenli: Uzaktan eğitimin ev ortamında gerçekleşmesi öğrenci ve öğretmenlerin okula gidiş ve gelişlerinde kaybolan zamanı ortadan kaldırmasıdır (Ö.31). Uzaktan eğitimde öğrenci kendini rahat hissediyor (Ö.4).

Ailelerin sürece aktif katılımını sağlıyor: Sınıfların evlerde olması anne babanın kontrolü ele alması öğrencesini eğitimsel boyutta daha yakından tanıması önemlidir (Ö.22). Sorumluluk benden çok velide oldu. Ayrıca veliler kendi ve çocuklarının eksiğini, dikkat durumlarını, derse katılımlarını ve eğitimsel durumlarını daha yakından gözlemle imkânı buldu (Ö.40).

Öğrenciyi araştırmaya sevk ediyor: Ders içeriklerini zenginleştirmek, için teknolojik imkânların kullanılması olumlu, öğrencilerin araştırmaya ve bilgiye sıcağı sıcağına ulaşması onların motivasyonu olumlu etkiliyor (Ö.33). Öğrencileri araştırmaya ve teknoloji etkin kullanmaya sevk etmiştir. Daha çok kaynak ve görselleri kullanabilme imkânı artmıştır (Ö.21).

Eğlenceli ve ilgi çekicidir: Öğrencilerin derse aktif katılımının önemli olduğu derslerden biridir öğrencilerin sosyal sorunlara ilişkin çözüm önerilerinin derste paylaşılmasıla derse olan ilgileri olumlu yönde etkilenmiştir (Ö.23).

Dijital içerikler öğrenmeyi kalıcı hale getiriyor: Çocukların yaratıcılıkları derse çok yansıdı. Farklı materyaller farklı ortamlar dersi eğlenceli ve kalıcı hale getirdi (Ö.34). Öğrencilerin sosyal bilgiler dersindeki başarısı arttı, özellikle ilgili öğrencilerde uzaktan eğitimde öğrendikleri daha kalıcı oluyor görüşündeyim (Ö.10). 
Daha hızlı öğreniliyor: Öğrenmeyi hızlandırıyor (Ö.1). Müfredatı yüz yüze eğitimden daha hızı bir sistem bu, öğretmede hızlı öğrenmeyi sağlıyor (Ö.39). Gezi veya tarihi bir olayı kolayca film, animasyon ya da kanitlarıla kolayca sunabilme imkânı tanıyan bir sistem. Bu yönüyle özellikle sosyal bilgiler dersleri için çok iyi ve hızlı öğreten bir sistem (Ö.15).

Uzaktan eğitim öğrencilere eşit söz hakkı sağlıyor: Öğrencilerin derse katılım ve eşit söz hakkı sağlamaktadır (Ö.8). Uzaktan eğitimin donanım açısından olmasa da ders işleyişler ve eğitimden yararlanmada öğrencilere eşit fayda sağlıyor (Ö.35). Uzaktan eğitim esnasında söz hakkı alamayan öğrenci tepkisini hemen koyduğu için öğretmende bu konuda daha dikkatli ve adil olmak durumda kaldı. Öğrencilere eşit söz hakkı verilmesi açısından uzaktan eğitimi daha uygun buluyorum (Ö.2).

\subsubsection{Sosyal Bilgiler Öğretmenlerinin Sosyal Bilgiler Dersi Açısından Uzaktan Eğitim Sürecinde Yaşanılan Sorunlara Yönelik Bulgular}

Sosyal Bilgiler öğretmenlerinin sosyal bilgiler dersi açısından uzaktan eğitim sürecinde yaşanılan sorunlara yönelik görüşleri Tablo 6.'da gruplanarak sunulmuştur.

Tablo 6: Sosyal Bilgiler Öğretmenlerinin Uzaktan Eğitim Sürecinde Ders Açısından

Sayfa | 1653 Karşılaşılan Sorunlara İlişkin Görüşleri

\begin{tabular}{l|l|l|l|l|l|l}
\hline Görüşler & \multicolumn{9}{c}{ Kıdem } \\
& $\mathbf{1 - 5}$ & $\mathbf{6 - 1 0}$ & $\mathbf{1 1 - 1 5}$ & $\mathbf{1 6 - 2 0}$ & $\mathbf{2 1 +}$ & \multicolumn{1}{l}{ T.G. } \\
\hline Alt yapı eksikliği & 3 & 3 & 2 & 2 & 3 & 13 \\
Derse katılım azlığı-kontrol zorluğu & 2 & 3 & 2 & 2 & 2 & 11 \\
Etkileşim ve eşit diyalog eksikliği & 2 & 2 & 2 & 2 & 2 & 10 \\
Değerlendirme yetersizliği & 2 & 2 & 2 & 2 & 2 & 10 \\
Öğretim süreçlerindeki tutarsızlıklar & 1 & 1 & 1 & 2 & 1 & 6 \\
Sosyalleşmede eksiklikleri & 2 & 1 & 1 & 1 & 1 & 6 \\
Esnek eğitimin doğru & 1 & 1 & 2 & 1 & 1 & 6 \\
kullanılmaması & & & & & & \\
Transaksiyonel uzaklık & 1 & 1 & 1 & 1 & 2 & 6 \\
Grup çalışması yetersizlikler & 1 & 1 & 1 & 2 & 1 & 6 \\
Fırsat eşitsizliği & 1 & 1 & 1 & 2 & 1 & 6 \\
\hline Toplam Görüş & $\mathbf{1 6}$ & $\mathbf{1 6}$ & $\mathbf{1 5}$ & $\mathbf{1 7}$ & $\mathbf{1 7}$ & $\mathbf{8 0}$ \\
\hline
\end{tabular}

Tablo 6'da sosyal bilgiler dersi açısından uzaktan eğitim sürecinde karşılaşılan sorunlara bakıldığında; alt yapı yetersizliği en önemli sorun olarak görülmektedir. Sosyal Bilgiler dersi açısından uzaktan eğitim sürecinde araştırmaya katılan 40 öğretmenin 13'i uzaktan eğitimin sorunlarına yönelik olumsuz görüşlerinde teknolojik ve eğitimsel alt yapı eksikliği olduğunu belirtmişlerdir. 11 öğretmen öğrencilerin derse 
katılımlarını kontrol edemediklerini belirtmişlerdir. Sosyal Bilgiler dersi açısından uzaktan eğitim sürecinde karşılaşılan sorunlara yönelik görüşlerden alıntılardan bazıları aşağıdaki sunulmuştur.

Sosyal bilgiler öğretmenlerinin sosyal bilgiler dersi açısından uzaktan eğitim sürecinde yaşanılan sorunlara yönelik görüşler şu şekildedir: Uzaktan eğitim sisteminin olmazsa olmazlarından olan bilgisayar, tablet, dijital medya havuzları ve diğer tüm kaynaklar her öğrencide mevcut değildir (Ö.11). Ekonomik durumu iyi olmayan öğrenci evde kardeşleriyle paylaştığı altyapı kullanımını nöbetleşe yapmaktadır. Bir evde üç öğrenci için üç bilgisayar bulunmuyor maalesef. Bu durumda öğretmen de öğrenciye ulaşamıyor. Alt yapı eksikliği sebebiyle eğitim öğretimden kopan öğrencilerimiz var (Ö.4). Aynı anda bir evde derse bağlanan kişi sayısı fazla olunca sesler birbirine karışıyor. Öğretmen açısından da öğrenci açısından da sıkıntılı süreçler yaşanmaktadır (Ö.23). İnternet sorunu, ses kamera sıkıntısı sorunlarının olması eğitimin kalitesini düşürüyor. Öğrencilerin bağlantı sorunu ve etkinliklerin yapılamaması. Uygulama ve materyal sıkıntısı. İnternet bağlantısı yetersizliklerinin olması yüzünden öğrencinin motivasyonu olmaması (Ö.39). Mikrofon, kamera, linkler vb. teknolojik dili ve donanımları kullanmayı bilmemeleri ilk zamanlar büyük bir sorun oluşturdu. Zayıf internet bağlantıları, telefondan girip ekranı tam Sayfa| 1654 algılayamama ve herkesi aynı anda görememe, çoğunlukla ekran üzerinden öğretmen tarafından tek taraflı bir paylaşımın yapılması, konu anlatımında yeterli örneklendirme için vakit kalmaması sistemin gitmesi, internet kesilmesi (Ö.15). Teknik altyapı yetersizliği, öğrencilerin uygulama yaparak dersini işleyebileceği materyal gerektiren konularda bu materyallerle temas halinde olmuyorum ancak uzaktan bakıyorum ve izliyorum (Ö.34).

Öğrencilerin derslere katılım sıkıntılarına ilişkin görüşler şunlardır: Öğrencilerin bir kısmına ulaşamamak beni sıkıntıya sokuyor. Her öğrenci erişim sağlayamıyor, öğrencilerin derslere katıımlarındaki kontrolü sağlamada yetersizlikler öğretmen olarak benim de motivasyonumu düşürüyor (Ö.36). Öğrencilerin internete ve teknolojik araç ve gereçlere yeterince ulaşamaması büyük sıkıntı (Ö.12). Derslere giren ancak ekranını açmayan ve kaliteli etkileşimde bulunmayan öğrencilerimin bu sorunlarını aileleriyle ve kendileriyle görüşerek bile çözemedim. Bu öğrenciler derslerde sadece dinleyici kalmayı tercih ediyorlar (Ö.5). Derslere katılan ancak hiç konuşmak istemeyen bir öğrenci yarattık uzaktan eğitimde. Çocukların bazıları suskun bir şekilde ilgisizce ders katılıyorlar ve sessizce dinliyorlar (Ö.17). Soru sorunca cevap alamıyorum. Çok sıkıştırınca ekranı kapatıp dersten çıkıyorlar, küçük sınıflarda daha çok oluyor bu davranış (Ö.21). Öğrencilerin derslere katılımları konusunda bir kontrolsüzlük yaşıyorum. 
Dersin başında gelip sonra dersten ayrılan öğrenciler var, onlara sorduğumuzda internet kesildi derslerde bazıları bunu bahane ediyorlar bende fark ediyorum ancak çözüm yolu bulamıyorum (Ö.23). Ekran sebebiyle öğrenci ile yakın ve kaliteli ilişki kuramıyorum, bu sebeple derse ve konuya ilgisi olmayan öğrencileri derse motive etmek zor oluyor. Çocuklar evdeki sanal dershane sistemini ve uzaktan eğitimi benimseyemediler. Öğrencilerin bir kısmına ulaşamamak büyük bir sorun. Dersi anlatırken sınıf ortamında en fazla iki kez tekrar ediyorsam, canlı derslerde bu sayı artabiliyor. Çünkü çocuk anlamamakta ısrar edebiliyor (Ö.2).

Etkileşim ve eşit diyalog eksikliği: Uzaktan eğitim sürecindeki eğitim yüz yüze eğitimdeki kadar etkili olmadığı kanısındayım. Yüz yüze eğitimde etkileşim ve iletişim daha etkiliydi. Motivasyon daha yüksekti (Ö.24). İkili diyalogları yetiştirememek, her öğrenciyle doğru etkileşim sağlayamamak öğrencilerde değersizlik yaratıyor ve psikolojik olarak dersten kopmuş oluyorlar (Ö.16). Uzaktan eğitimde herkese eşit olarak söz hakkı ve ilgi verilmiyor. Çünkü ders süresince derse eşit oranda derslere katmak imkânsız oluyor. Hem süre sıkıntısı hem de derse katılım da isteksizlik buna engel oluyor (Ö.35).

Değerlendirme yetersizliği: Değerlendirme yapamıyoruz ve sürecin Sayfa | 1655 nasıl ilerlediğini kestiremiyoruz. Değerlendirme konusunda uzaktan eğitim sadece akademik değerlendirme yapabiliyor ancak kültür, sanat ve beceri eğitimlerini değerlendirecek bir uygulama henüz yok (Ö.1). Uzaktan eğitimde öğrenciyi birebir değerlendiremiyorum. Yaptığı herhangi bir çalışmayı anında düzeltemiyorum. Öğrencinin konuyu anlayıp anlayamadığı konusu geri bildirim alamıyorum. Bu benim için en büyük sorun olmakta. Öğrencinin konuyu ne derece anladığı kestiremiyorum (Ö.16). Öğrencinin defter, kitaba aktardığını kontrol edememe, yazılı bir değerlendirmenin mümkün olmaması. Sınavdan yana olmasam da eğitim süreçlerinin değerlendirilmesi gerektiğine inanıyorum ancak bunu uzaktan eğitimde yapamıyorum. Uzaktan eğitimde çevrimiçi sınavlar dışında başka bir şekilde değerlendirme yapamamak büyük sıkıntı (Ö.33). Gece değerlendirmede soruların uzun cevaplarını okuyorum ancak öğrenciye bu cevaplardaki hatalarını nasıl geri dönüş yapıp düzelteceğimi düşünüyorum. Daha fazla zaman gerekiyor bireysel değerlendirmeler için. Açık uçlu sorular uzaktan eğitimde hiç iyi olmuyor. Daha kolay bir değerlendirme yolu olmalı. Bu çok ve sıkıntılı bir durum (Ö.5). Öğrencide geliştireceğim okuma, araştırma, yazma, sunma becerilerini nasıl ölçeceğim konusunda sıkıntılarım var (Ö.28). Ölçme değerlendirme sadece test yoluyla ölçüm yapabiliyorum şu an başka bir şekilde çocuklara ulaşamıyorum ve onların çalışmalarını 
ölçemiyorum. Onların davranışlarını gözlemleyerek hiçbir ölçüm yapılmıyor bu sistemde. Zaten onların neyi nasıl yaptıklarına yönelik bilgi eksikliklerimiz var. Başka bir değerlendirme yolu olmalı (Ö.15).

Eğitim-öğretim süreçlerindeki tutarsızlıklar: Ders programlarının ve derslerin uzaktan eğitime uyarlanmasının doğru olmadı diye düşünüyorum. Ders saatlerinin çok fazla olması uzaktan eğitimin sorunlarından biridir çünkü yüz yüze eğitimde çocuk hareketli ama ekran karşısında sabit durması gerekiyor. Küçük çocuklar bunu yapamıyorlar maalesef (Ö.24). Sosyal bilgiler dersinden kazanımlar bir anda çok yüzeysel olarak başlıyor ama MEB dışındaki tüm yayınlarda $k$ oldukça detaylı ele alınmış. MEB kitapları yüzeysel ve sistemsiz hazırlanmış. Kazanımların derinliği konusu biz öğretmenlere bırakılmış görünüyor. Konuları uzaktan eğitimle zenginleştirmeye ve derinlemesine anlatmaya kalkışırsak öğrencilere ağır geliyor. Ders yükü çok ders saatleri az geliyor (Ö.5). MEB'den gelen anlaşılmaz net olmayan bazı yönetmeliklerin, öğretmenlerin motivasyonunu olumsuz yönde etkilediğini düşünüyorum. Öğretmen olarak grup çalışmalarında yöntem ve alt yapı eksiklikleri sebebiyle sıkıntı çekiyoruz herkes evinde bireysel olduğu için bu konuda zorlukları var. Kurumların çok fazla desteği olmuyor. Öğretmenler bireysel çözüm üretiyorlar (Ö.18). Sürekli değişiklik gösteren bakanlık açıklamaları sıkıntı yaratıyor, sorunlara Sayfa | 1656 çözüm üretmiyorlar aksine sorun çıkarıyorlar. Ülkemizdeki eğitim süreçleri konusunda sürekli değişim ve sürekli tutarsız açıklamalar biz öğretenleri yoruyor ve süreçten uzaklaştırıyor. Eğitimde gelişen olayları öğretmenlerin sorumluluğu gibi gösterilmesi beni öğretmenlik mesleğimden soğutuyor (Ö.22). Nasıl bir eğitim vereceğini maalesef iyi planlanmıyor ve sorumlusu olarak öğretmenleri gösteren açıklamalar yapılıyor. Uzaktan eğitim sürecindeki yapılan uygulamalar tutarsızlıklarla dolu, uzaktan eğitimde başarılı bir eğitim politikası olmalı. Eğitim sisteminde hiçbir uygulama yeterli düzeyde iyi ve kaliteli değil (Ö.3). Öğretmenler uzaktan eğitimde yalnı başlarına eğitim öğretim veriyorlar. Uzaktan eğitim sisteminin öğretmene daha çok sorumluluk ve yük getirdi kanısındayım, bunlara rağmen öğretmenleri emeklerinin hiçe sayıldığı tutarsız açıklamalar beni mesleğimden soğutuyor (Ö.35).

Sosyalleşme eksiklikleri: Sosyal bilgiler dersinin amacı çocuğun sosyalleşmesine aracı olmaktır ancak uzaktan eğitimde sosyalleşme konusunda eksiklik oluşuyor. Çünkü çocuklar bir ekranın arkasında kendilerini yalnız hissediyorlar. Sosyal katılım öğrencilerde henüz gelişmediğinden yalnızlık duygusu öğrencilerin psikolojik sorunlarının oluşmasına sebebiyet vermektedir (Ö.30). Öğrencilerin sosyal katılım duygusunda eksiklikler oluyor. Ders yükü, çok süresi yetersiz kalıyor. 
Okuldaki yüz yüze eğitimde öğrenciler sosyal ortamlarda akranlarından da birçok davranışı görür ve öğrenir. Uzaktan eğitimde akran öğrenmesi yerine ekran öğrenmesi olduğu için sosyalleşmede sıkıntılar yaratmaktadır Bilgisayar başında insanlar nasıl sosyalleşirler ki? Bir öğretmen olarak ben bile buna inanmıyorum (Ö.5).

Esnek Eğitimin Doğru Kullanılmaması: Öğretmen açısından çok sıkıcı olmaya başladı. Esnek eğitim iyi olabilir ama bunun bir süresi sınırları olmalı. Sabahtan akşama kadar uzaktan eğitim veren biz öğretmenlerin dinlenecek zamanı kalmıyor maalesef. İşimizin tüm güne tüm hayatımıza yayılması özel hayatımızı alt üst etti (Ö.25). Okul yönetimi size istediği saatte ders atayabiliyor. Atamalar sabah 8 akşam 9 saatleri arasında değişiyor. Bu durum aile yaşantınızı kötü yönde etkiliyor. Günün her saatinde derse hazır olmanız lazım, evdeki sorumluluklarınızı (ev işi, çocuk bakımı, çamaşır, bulaşık, çocukların eğitimi yerine getirmeniz lazım, ders materyaliniz hazır olması lazım. Çünkü okul programınızda farklı seviyedeki öğrencilere dersiniz vardır. Bunlar büyük sıkıntı oluşturuyor (Ö.3). Eğitim hızı benim elimde. İstediğim zaman telafi edebiliyorum. Esnek zaman olması çok iyi. Ancak kişisel zaman ve özgürlükler açısından olumsuzluk yaratıyor (Ö.18). Dersi aktif olarak işlemek de sizin becerinize kalmış. Tabi tüm bunların yanında kendi psikolojinizi sağlam tutmamız lazım. Yüz yüze eğitim verirken Sayfa| 1657 okul ortamı sizi canlı tutuyor, uzaktan eğitim bizi canlı tutmaktan çok uzak. Kişisel bakım, kıyafet, sosyallik, projeler, toplantılar (Ö.9). Uzaktan eğitim öğretmenin özel zamanını almaktadır. Uzaktan eğitimlerinin planlamasındaki eksiklikler, gece gündüz eğitim ve değerlendirme saatleri birbirine girmiş durumda. Aileme zaman ayıramıyorum, çok iş yükü var ve saati belli değil. Öğrencilere her an her saniye cevap verecek öğretmenin yaratılması maalesef esnek eğitim değil özel zaman ihlalidir. Uzaktan eğitim öğretmenin işini ve mesaisini tüm güne yaydı. Uzaktan eğitimde mesai diye bir kavram kalmadı artık. Derse katılamayan öğrencilerimiz için bireysel çözümler üretiyoruz ancak ders saati artıyor ve bizlere özel bir zaman kalmıyor (Ö.36).

Transaksiyonel uzaklığın etkileri (uzaklıktan kaynaklı, boşluk ve yalnızlık hissi): Öğrencilere yeterince ulaşamıyorum, kaliteli diyalog ve etkileşimde bulunamıyorum, gerekli motivasyonu sağlayamıyorum (Ö.14). Öğrenci ekran karşısında yalnızlık duygusunu dile getiriyor. Ben de öğretmen olarak aynı duyguyu sık sık hissediyorum (Ö.19). Okulu seven biri olarak ben uzaktan eğitimde öğrencilerimden çok uzakta gibi hissediyorum. Arada oluşan boşluk asla kapanmıyor. (Ö.5). Öğrenciyle aramda oluşan uzaklık duygusunun üstesinden gelemiyorum. Bu benim eğitim öğretim sürecimi olumsuz etkiliyor (Ö.35). 
Grup çalışması yetersizlikler: Öğrencilerle grup çalışması yapamıyorum Uzaktan eğitimde henüz grup çalışması yapmadım, yapamadım. Grupları bir araya getirmek büyük sıkıntı (Ö.37). Grup çalışması için ödev veriyorum ama öğrenciler kontrol alanı dışında oldukları için bilgisayarda oyuna dalıyorlarmış. Uzaktan eğitimde grup çalışmalarında sıkıntı var (Ö.4).

\subsubsection{Sosyal Bilgiler öğretmenlerinin sosyal bilgiler dersi eğitimine yönelik sorunlarının çözümüne yönelik önerilerine ilişkin bulgular}

Sosyal Bilgiler öğretmenlerinin sosyal bilgiler dersi eğitimine yönelik sorunların çözümüne ilişkin önerileri Tablo 7'de gösterilmiştir.

Tablo 7: Sosyal Bilgiler Öğretmenlerinin Uzaktan Sosyal Bilgiler Dersi Eğitimine Yönelik Sorunların Çözümlerine İlişkin Önerileri

\begin{tabular}{l|l|l|l|l|l|l}
\hline Görüşler & \multicolumn{6}{|c}{ Kıdem } \\
& $\mathbf{1 - 5}$ & $\mathbf{6 - 1 0}$ & $\mathbf{1 1 - 1 5}$ & $\mathbf{1 6 - 2 0}$ & \multicolumn{2}{c}{$\mathbf{2 1 +}$ T. G. } \\
\hline Alt yapı ücretsiz ve yeterli olmalı & 3 & 4 & 4 & 3 & 5 & 19 \\
Ders yükü, ders sayısı azaltılmalı & 2 & 4 & 2 & 2 & 2 & 12 \\
Canlı ders süresi kısaltılmalı & 1 & 2 & 2 & 2 & 3 & 10 \\
Hizmet içi eğitim alınmalı & 1 & 2 & 2 & 1 & 2 & 8 \\
Uzaktan eğitim müfredatı olmalı & 1 & 1 & 1 & 2 & 1 & 6 \\
Öğretmenlere ek ücret verilmeli & 1 & 1 & 1 & 1 & 1 & 5 \\
Farklı değerlendirmeler olmalı & 1 & 1 & 1 & 1 & 1 & 5 \\
Uzaktan eğitim hiç olmamalı & 1 & 1 & 1 & 1 & 1 & 5 \\
\hline Toplam Görüş̧ & $\mathbf{1 1}$ & $\mathbf{1 6}$ & $\mathbf{1 4}$ & $\mathbf{1 3}$ & $\mathbf{1 6}$ & $\mathbf{7 0}$ \\
\hline
\end{tabular}

Tablo 7'de görüldüğü gibi, görüldüğü gibi, sosyal bilgiler dersi öğretmenlerin 19'u için uzaktan eğitim için kullanılan teknolojik alt yapının ücretsiz ve yeterli olmasını önermişlerdir. Ders yükü, ders sayısı azaltılmalı, canlı uzaktan eğitim süresi kısaltılmalı, öğretmenler hizmet içi eğitim almalılar, uzaktan eğitim müfredatı olmalı, öğretmenlere ek ücret verilmeli, sınavlar yerine farklı değerlendirmeler olmalı, uzaktan eğitim hiç olmamalı" şeklinde önerilerde bulunmuşlardır. Ders yükünün ve konuların çok fazla olduğu canlı yayınların bu nedenle arttığını bu durumda öğrencilerde bıkkınlık yarattığını belirten öğretmenlerden alınan görüş sayısı 12'dir.Canlı yayın ile uzaktan eğitim ders saati süresinin 40 dakika olmaması gerektiğini ifade eden 10 sosyal bilgiler ders öğretmeni olmuştur. Öğretmenlerin hizmet içi programlarına alınması ve ders etkinliklerini kendilerinin oluşturmaları yönünde öneriler 8 görüş ile belirtilmiştir. Uzaktan sosyal bilgiler dersi eğitimine yönelik sorunlarının çözümlerine ilişkin öneriler konusunda yapılan alıntılardan bazıları şu şekildedir: 
Alt yapı eksikliği giderilmeli: Altyapı sistemleri herkese ücretsiz ve yeterli olmalı (Ö. 37). Öğretmen olarak grup çalışmalarında yöntem ve alt yapı eksiklikleri sebebiyle sıkıntı çekiyoruz, herkes evinde bireysel olduğu için bu konuda zorlukları var (Ö.5). Uzaktan eğitimde öğretmenlere eğitim öğretim süresince kurumların çok fazla desteği olmuyor. Öğretmenler bireysel çözüm üretiyorlar. Uzaktan eğitimde öncelikli olarak altyapı sağlam yapılmalıdır (Ö.9). Öğretmenler hizmet içi eğitimlerden yararlanmalılar. Ben kendimi yetiştirmek için zamanla yarışıyorum ama yine de çok büyük eksikliklerim var. Bu konuda herhangi bir eğitim almadım (Ö.16). Öğretmenler alt yapıyı ve eğitimsel materyalleri kendileri sağlıyor. Biz öğretmenler bilgisayarlarımızı, tabletlerimizi, internetimizi ve eğitim materyal havuzumuzu kendimiz sağlıyoruz. Uzaktan eğitimde kullanılacak her şey oldukça pahalı. Bunun vergilerimizle devletin karşılaması daha doğru olur. Eğer yapamayacaksa öğretmenlere bunun için ek ücret ödemelidir (Ö.24).

Ders yükü ve ders sayısı azaltılmalı: Günlük ders saatleri çok uzun ve fazla. Ders sayısı en asgariye indirilmeli. Ancak ilgi ve isteğe göre seçmeli derslerin sayıları arttırılmalıdır (Ö.8). Dersler hem uzun hem de sayıları çok fazla. Öğrencileri bu kadar uzun süre ekran karşısında tutmak sakıncalı bu nedenler ders saatleri ve derslerin süreleri azaltılmalı (Ö.21). Öğrencilere Sayfa| 1659 uzaktan eğitimde seçmeli derler sunulmalıdır. Öğrenci isterse bu derslere girmelidirler. Mecburi ders saatleri çok fazla ve ders süreleri uzun olunca dikkat ve motivasyonu toplamada sıkıntılar var bunları azaltmak gerekiyor (Ö. 15).

Canlı uzaktan eğitim süresi kısaltılmalı: Canlı derler çok uzun bütün gün hem öğretmenler hem öğrenciler büyük sıkıntı çekiyorlar. Ben bu kadar uzun olmasının yararlı olduğuna inanmıyorum (Ö.32). Uzaktan eğitimin en büyük sorunu budur. Canlı ders sayısı ve süreleri konusunda öğretmen olarak çocukları ekran başında tutmaktan dolayı çok zorlanıyorum. Canı ders süreleri çok uzun 20 dakika olabilir (Ö.26).

Öğretmenler hizmet içi eğitim almalı: Öğretmen olarak eksikliklerimiz oluştu. Biz uzaktan eğitim öğretmeni değiliz. Bu farklı bir süreç. Sürece çok zarar vermeden yararlı olmak için bizim bu konuda eğitim almamı gerekmektedir (Ö.24). Ben yüz yüze eğitim öğretme tekniklerini biliyorum. Bu benim işim değil ki, eğitim almadan uzaktan eğitim yapmamızı istemek büyük hata, yapamıyoruz zaten (Ö.25).

Uzaktan eğitim müfredatı olmalı Öğretim süreçlerini değerlendirme de sınavların olmaması ancak öğrencilerin öz değerlendirme yayabilmelerine olanak sağlayıcı uygulamaların geliştirilmesi gerekmektedir (Ö.13). 
Öğrencilerin öz düzenleme ve öz değerlendirme yapabilecekleri bir uzaktan eğitim sistemine ihtiyacımız mevcuttur (Ö.34).

Öğretmenlere ek ücret verilmeli: Uzaktan eğitim öğretmenleri değiliz ve bu sürecin içinde çok çalışıyoruz. Mesai saatlerimiz ortadan kalktı. Bize ek ücret ödemeleri gerekiyor (Ö.15). Tüm gün ve gece çok çalışıyorum ancak aldığımız ücreti bile vermeyi istemiyorlar bunu kabullenmek zorunda bırakıyorlar. Öğretmen olarak uzaktan eğitim fazla mesai gerektirdiği için bizlere ek ödenek vermeleri de gerekiyor (Ö.4).

Sınavlar yerine farklı değerlendirmeler olmalı: Yüz yüze eğitim sınavları ile online eğitim sınavları arasında fark çok. Bunları birbirine karıştırmamak gerekiyor. Sınavlar kalkmalıdır (Ö.28). Değerlendirme kriterleri yeniden ele alınmalıdır. Böyle uzaktan değerlendirme olmuyor, sadece test sınavı iyi oluyor gerisi başarısız (Ö.3).

Uzaktan eğitim hiç olmamalı: Öğrencilerin ileriki yaşantılarında internet bağımlılığı, göz ve omurga bozukluğu sebebinin uzaktan eğitim eğitimdir, çocuklar sağlık ve sosyal anlamda çok fazla zarar görmektedirler. Bu nedenle uzaktan eğitim hiç yapılmamalıdır (Ö.1). Uzaktan eğitim çocukların psikolojik ve fizyolojik yapısını bozuyor. Çocukları hasta eden bu sistem hiç yapılmamalıydı. (Ö.28). Uzaktan eğitim parayla yapılacak güzel bir sistem Sayfa | 1660 ancak fakir ülkeler bunu karşılayamazlar o yüzden uzaktan eğitim fırsat eşitsizliği yaratmaktadır. Bu nedenle bu uygulamanın hiç yapılmaması gerekiyor (Ö.7).

\subsubsection{Sosyal Bilgiler Öğretmenlerinin Sosyal Bilgiler Dersinde Etkili Bir Öğretim Olabilmesi İçin Uzaktan Eğitim Önerilerine İlişkin Bulgular}

Sosyal bilgiler öğretmenlerinin Sosyal bilgiler dersinde etkili bir öğretim olabilmesi için uzaktan eğitim önerilerine ilişkin görüşleri Tablo 8'de gösterilmiştir.

Tablo 8: Sosyal Bilgiler Öğretmenlerinin Dersinde Etkili Bir Öğretim Olabilmesi İçin Uzaktan Eğitim Önerileri

\begin{tabular}{llcccccc}
\hline Görüşler & $\mathbf{7}$ & $\mathbf{6 - 1 0}$ & $\mathbf{1 1 - 1 5}$ & $\mathbf{1 6 - 2 0}$ & $\mathbf{2 1 +}$ T.G. \\
\hline Uzaktan eğitim müfredatı olmalı & 3 & 4 & 4 & 3 & 5 & 19 \\
$\begin{array}{l}\text { Dijital derslere uygun yöntem ve } \\
\text { teknikler geliştirilmeli }\end{array}$ & 2 & 4 & 2 & 2 & 2 & 12 \\
$\begin{array}{l}\text { Beceri ağırlıklı sosyal bilgiler olmalı } \\
\text { İçerikler zenginleştirilmeli }\end{array}$ & 1 & 2 & 2 & 2 & 3 & 10 \\
$\begin{array}{l}\text { Öğretmenler hizmet içi eğitimlere } \\
\text { alınmalı }\end{array}$ & 1 & 2 & 2 & 1 & 2 & 8 \\
\hline
\end{tabular}


Şengül Korkut - Hatice Memişoğlu

\begin{tabular}{|c|c|c|c|c|c|c|}
\hline $\begin{array}{l}\text { Her öğretmen ve öğrenciye teknik } \\
\text { donanım sağlanmalı }\end{array}$ & 1 & 1 & 1 & 1 & 2 & 6 \\
\hline Sınıflardaki öğrenci sayısı azaltılmalı & 1 & 1 & 1 & 1 & 1 & 5 \\
\hline Ders süreleri azaltılmalı & 1 & 1 & 1 & 1 & 1 & 5 \\
\hline Toplam Görüş & 11 & 16 & 14 & 13 & 18 & 73 \\
\hline
\end{tabular}

Tablo 8'da görüldüğü gibi, etkili bir uzaktan sosyal bilgiler öğretimi için dersin yapısına uygun yöntem ve teknik geliştirilmesi gerektiğini ifade edilmiştir (12 görüş). Bilgiye erişimde sıkıntı olmadığını ancak beceri eğitimlerinde uzaktan eğitimin yetersiz kaldığını ifade eden öğretmenler uzaktan eğitiminde beceri eğitimlerini destekleyici bir şekilde yeniden tasarlanması gerektiğini belirtmişlerdir (10). Sosyal bilgiler dersi öğretiminde içerik zenginliği ve derinliği oluşturulması gerektiği önerilmiştir. Öğretmenlerin hizmet içi eğitimlerde uzaktan eğitim öğretmenliği eğitici eğitimlerini almaları önerilmiştir (6). Kalabalık sınıflarda ses kirliliği nedeniyle uzaktan eğitimin kalitesinin düştüğü bu nedenle sınıfların daha az öğrenci sayılarıyla oluşturulması önerisi yapılmıştır (5). Ders sürelerinin azaltılması gerektiği ifade edilmiştir.

Sosyal bilgiler öğretmenlerinin sosyal bilgiler dersinde etkili bir öğretim olabilmesi için uzaktan eğitim önerilerine ilişkin görüşlerden bazıları şu şekildedir:

Uzaktan sosyal bilgiler eğitimi müfredatı olmalı: Uzaktan eğitime uygun sosyal bilgiler müfredat programı olmalı. Bu müfredatta yüz yüze eğitimde uygulanan bazı şeyle uzaktan eğitimde yapılamıyor (Ö.22).

Dijital derslere uygun yöntem ve teknikler geliştirilmeli: Yöntem ve tekniklerde uzaktan eğitimde sıkıntı çekiyorum. Dersleri işlemekte olmuyor, daha farklı ve dijital ortamlara uygun tekniklerimiz olmalı (Ö.5).

Beceri ağırlıklı sosyal bilgiler dersi olmalı: Sosyal bilgiler dersinde bilgiye ulaşmada sıkıntılarım yok ancak beceri ağırlıklı bir sosyal bilgiler dersi tasarlanmalı çünkü öğretmenler bilgi taşıma işini artık yapmıyorlar, bilgi her yerde, öğrencilerin beceri ağırlıklı eğitim almaları gerekmektedir. Sonuçta çok bilgili çok beceriksiz öğrenciler yetişiyor. Eğitimde amaç bu değil (Ö.37).

İçerikler zenginleştirilmeli tüm öğretmenler eşit bir şekilde kullanabilmeli: İçerik çok gibi görünse de aslında her dersin havuzu olmalı. Bu havuzda zengin içerikler olmalı ve kilit sistemi olmamalı, öğretmenler her an her durumda bu içeriklerden yararlanmalı (Ö.16). Bazı öğretmenler zengin içeriklerden yararlanamıyor, bunun nedeni erişim eşitsizliğidir ve ekonomiktir (Ö.28). 
Öğretmenler hizmet içi eğitimlere alınmalı. Uzaktan eğitime göre yetiştirilmedim. Benden beklenen çok fazla bilmediğim şey var. Öğretmen olarak hizmet içi eğitimlere ihtiyacım var (Ö.15). Uzaktan eğitimi öğrenmek için zamana ve eğitime ihtiyacım var. Teknolojik eğitim farklı bir şey bu kadar hafife alınmamalı (Ö.37).

Her öğretmen ve öğrenciye teknik donanım sağlanmalı: Devlet okulundayım ve özel okullardaki gibi zengin ders içeriklerim ve alt yapım yok (Ö.8). Teknolojik alt yapı ve ders içerikleri herkese ücretsiz sunulmalı ve bu konuda eğitimde eşitsizlikler ortadan kalkmalıdır. Bu eğitimden eşit bir şekilde yararlanmada adaletsiz bir durum yaratıyor (Ö.21).

Sınıflardaki öğrenci sayısı azaltılmalı: Sınıfım 42 kişilik bir sınıf ve çok kalabalık. Sesimi duyuramıyorum. Uzaktan eğitim sınıflarında en fazla 15 öğrenci olmalı. Daha fazlası eğitimi aksatmaktadır (Ö.18). Sessizlik çok önemli. Sesler üst üste gelince dersler çekilmez oluyor bu nedenle kalabalık sınıflar yerine en fazla 10 kişilik gruplarla ders işlense daha iyi olabilir, ancak bu da bizim mesai saatlerimizi arttırıyor. Kayıtlardan dinlenebilir dersler (Ö.7).

Ders süreleri azaltılmalı: Ders süreleri çok uzun, ders sayıları fazla. Bazı derler mecburiyetten çıkarılmalı, seçmeli olmalı (Ö.29) Sosyal bilgiler ders Sayfa | 1662 sayısını az buluyorum. Temel dersler dışında iyi bir zamanlama ve planlama ile seçmeli dersler daha olmalı (Ö.40.) Bu derslerde sosyal bilgiler dersi en az iki saat olmalı ve derse ilgisi olan öğrenciler derslere girmeli. Her öğrenci sosyal bilgiler dersine girmek zorunda bırakılmamalı. Seçmeli kayıtlardan izlenilen dersler konulabilir (Ö.3).

\section{2. İkinci Alt Probleme İlişkin Bulgular}

İlkokul ve ortaokul öğrencilerinin Sosyal bilgiler dersi açısından uzaktan eğitime yönelik görüşlerine ait bulgular tablolaştırılarak, alıntılarla birlikte verilmiştir.

\subsection{1. Öğrencilerin Sosyal Bilgiler Dersi Açısından Uzaktan Eğitime Yönelik Olumlu Görüşleri}

Öğrencilerin Sosyal Bilgiler dersi açısından uzaktan eğitime yönelik olumlu görüşleri Tablo 9'da sunulmuştur. 
Tablo 9: Öğrencilerin Uzaktan Eğitime Yönelik Olumlu Görüşleri

\begin{tabular}{l|l|l|l|l|l}
\hline Görüşler & \multicolumn{5}{|c}{ Sınıf Düzeyleri } \\
& $\mathbf{4}$ & $\mathbf{6}$ & $\mathbf{7}$ & T.G. \\
\hline Rahat, güvenli ve kolay olması & 3 & 6 & 4 & 6 & 19 \\
Zamandan tasarruflu olması & 1 & 2 & 3 & 4 & 13 \\
Öğrenmenin daha hızlı olması & 2 & 2 & 5 & 3 & 12 \\
Motivasyon artışını sağlaması & 2 & 2 & 4 & 2 & 10 \\
Zengin görsellerinin olması & 3 & 2 & 3 & 2 & 10 \\
Sınavların daha az yapılması & 3 & 3 & 2 & 2 & 10 \\
Ders kayıtlarına sonradan ulaşılması & 2 & 1 & 3 & 3 & 9 \\
\hline Sınıflara Göre Toplam Görüş & $\mathbf{1 6}$ & $\mathbf{1 8}$ & $\mathbf{2 4}$ & $\mathbf{2 2}$ & $\mathbf{7 7}$ \\
\hline
\end{tabular}

Tablo 9'a göre; İlkokul ve ortaokul öğrencileri uzaktan eğitimin, sabah erkenden kalkmak zorunda olmaması ve eğitimin evden sürdürülebilmesinin büyük bir rahatlık ve kolaylık sağladığını (19), okula gidişin olmamasının öğrencilere zamandan tasarruf kazandırdığını (13); öğrenmenin daha hızlı olmasını (13), uzaktan eğitimin motivasyonu arttırmasını (12), sınavların daha az sayıda yapılmasını (10), ders kayıtlarına sonradan ulaşılarak yeniden izlenebilmesini (9), eğitim açısından olumlu bulduklarını ifade etmişlerdir. Öğrencilerin uzaktan eğitime yönelik olumlu görüşleri şu şekildedir:

Rahat, güvenli ve kolay olması: Uzaktan eğitimin en güzel yanı evde, rahat bir ortamda ve bu konuda kolaylıklar sağlaması (Ö.7). Okula gitme derdi yok, kurallar yok, kişisel sorunlarla başa çıkma yok, arkadaşlarımla sorun yok. Bunlar çok güzel (Ö.35).

Zamandan tasarruflu olması: Zamandan tasarruf ediyoruz, servis tok. Evde rahatım. Çok hasta olduğumda derse girmem bile gerekmiyor (Ö.27). Derslere giremediğim zaman ders kayıtları benim yeniden bu dersi dinlemem yarıyor. Bu çok iyi oluyor (Ö.21). Bildiğim konular için derslere girmiyorum ve zaman kaybetmiyorum. Bence bu uzaktan eğitimin en olumlu yanı (Ö.6) Okula giderken de zaman kaybediyorduk, o da bitti (Ö.13). Öğrenmenin daha hızlı oluyor. (Ö.34). Uzaktan eğitim bana çok yarıyor. Daha hızlı öğreniyorum. Benim için iyi oldu bu durum (Ö.39).

Zengin görsellerin olması: Ben görsel okumayı çok seven biriyim ve uzaktan eğitim resimli videolu ve şekilli olduğu için çok iyi öğrenebiliyorum. Dikkatim yüksek oluyor. (Ö.2). Zengin görsellerle ilgim daha çoğaldı, öğretmen ne gösterecek diye merak ediyorum hatta (Ö.32).

Motivasyon artışını sağlaması: Uzaktan eğitim ilgimi çekiyor. Ben çok memnunum. Okula gitmekten çok iyidir. Daha iyi ve istekli derslere giriyorum (Ö.37). Evde rahat olunca derslere katılma isteğim de iyi oluyor 
(Ö.34). Zengin görsellerinin olması (Ö.6). Ders içeriklerinde zengin görseller kullanılıyor ve benim derse motivasyonumuz biraz daha arttı.

Öğrenmenin hızlı olması: Bu sistem öğrenmeyi çok iyi sağlıyor ama uygulamayınca unutuluyor. Oysa gerekli tekrarlar yapılırsa öğrenme yüz yüze eğitimden daha hızlı bana göre (Ö.13). Boşa zaman kaybetmiyorum ve daha çok bilgiyi daha az zamanda edinebiliyorum. Uzaktan öğretim benim için çok ideal (Ö.19).

Sınavların daha az yapılmasına yönelik öğrenci görüşlerinden bazıları: Bu aralar çok fazla sınav olmayınca rahat ettim. Not korkum azaldı biraz (Ö.19.) Uzaktan eğitimde oluşan bazı sıkıntılarımızı öğretmenler anlıyorlar, bu yüzden çok sınavlarla üstümüze gelip moralimizi bozmuyorlar (Ö.23). Çok fazla sınav benim psikolojimi bozuyordu. Uzaktan eğitimde bizi sınava boğmayan bir sistem. Kendi kendimizi deneme firsatımız daha fazla. Başkalarının kontrolü yerine kendi kendimi kontrol ederek gelişim sağlamak işime geliyor (Ö.38).

Ders kayıtlarının olması: Eğitim sitesindeki dersleri yeniden dinleyebilmek çok yararlı oluyor (Ö.2). Dersleri kaçırdığımda kayıtlardan ders dinleyebiliyorum. Bildiğim derslere de girip zaman kaybetmiyorum (Ö.14). Uzaktan eğitimde eksik kaldığım yerlerde bile internette anında Sayfa| 1664 daima zengin içerik buluyorum ve kayıtlardan eksikliklerimi bakıp kontrol edebiliyorum (Ö.26). İşlenilen dersin eğitim portalında kayıtlarının olması çok işime yarlyor. Dersleri sonradan izleyebiliyorum. Eksiklerime tekrar bakma şansım olabiliyor (Ö.15).

\subsection{2. Öğrencilerin Sosyal Bilgiler Dersi Açısından Uzaktan Eğitimin Olumsuz Bulunan Yönlerine İlişkin Görüşleri}

İlkokul ve ortaokul öğrencilerinin Sosyal bilgiler dersi açısından uzaktan eğitimin olumsuz bulunan yönlerine ilişkin görüşleri tablo 10'de sunulmuştur.

Tablo 10: Öğrencilerin Uzaktan Eğitime İlişkin Olumsuz Görüşleri

\begin{tabular}{l|l|l|l|l|l}
\hline Görüşler & \multicolumn{5}{c}{ Sınıf Düzeyleri } \\
& $\mathbf{4}$ & $\mathbf{5}$ & $\mathbf{6}$ & $\mathbf{7}$ & T.G. \\
\hline İnternetin sık sık kesilmesi & 4 & 2 & 3 & 3 & 12 \\
Ders yükünün çok fazla olması & 4 & 3 & 2 & 1 & 10 \\
Seslerin üst üste gelip karışması & 3 & 2 & 3 & 2 & 10 \\
Yalnızlık hissi uyandırması & 3 & 2 & 2 & 3 & 10 \\
Öğretmene ulaşılmaması & 3 & 2 & 3 & 2 & 10 \\
Arkadaşlarımla ilişkilerimin azalması & 3 & 3 & 2 & 2 & 10 \\
Sürekli dinleyici olunması & 2 & 3 & 2 & 2 & 10 \\
Ekranda dersin yorucu olması & 2 & 2 & 3 & 2 & 9 \\
\hline
\end{tabular}




\begin{tabular}{l|l|l|l|l|l}
\hline $\begin{array}{l}\text { Öğretmenlerin günün her saatinde } \\
\text { ders ataması }\end{array}$ & 3 & 2 & 2 & 2 & 9 \\
\hline Sınıflara Göre Toplam Görüş & $\mathbf{2 7}$ & $\mathbf{2 1}$ & $\mathbf{2 2}$ & $\mathbf{1 9}$ & $\mathbf{9 0}$ \\
\hline
\end{tabular}

Tablo 10'da görüldüğü gibi, öğrencilerin olumsuz görüşleri içine en fazla görüş, internetin sık sık kesintiye uğraması olmuştur. Ders saatlerinin fazla olması, internette toplu konuşmalarda seslerin üst üste binmesi ve rahatsız etmesi, ders esnasında öğrencilerin yalnızlık hissetmesi, sesler sebebiyle öğretmene ulaşmada sıkıntıların oluşması, arkadaşlık ilişkilerinin azalması, ekran karşısında çoğu kez dinleyici olarak kalınması, ekran ışığının insan gözünü ve beynini yorması, öğretmenlerin esnek zamanı istedikleri şekilde kullanarak günün her saatini derslerle doldurmaları, oyuna, sanat, kültüre ve arkadaşlık yapmaya zamanın kalmamasını birer olumsuzluk olarak ifade edilmiştir. Öğrencilerinden gelen uzaktan eğitime dair olumsuz görüşlerden alıntılar şu şekildedir:

Kesintiler dikkatimi dağıtıyor: Tam derslere odaklandığımda internetim kopunca moralim bozuluyor. Canım bir şey yapmak istemiyor (Ö.5). En büyük olumsuzluk internetin sık sık kesilmesi bence. İnsan ne yapacağını şaşırıyor (Ö.13). Sistem bizi ve öğretmeni atıyor ve öğretmen son dakika söyleyeceği şeyleri söyleyemiyor. Yüz yüze eğitimde bu zorlukların hiçbiri yok (Ö.14).

Ders yükünün çok fazla olması: Dersleri öğreniyorum ama çok yoruluyorum ve dersler çok fazla, saatleri çok fazla (Ö.23.) Uzaktan eğitim istemiyorum yüz yüze eğitim olmasını istiyorum. Uzaktan eğitimde bir şey anlamıyorum (Ö.9). Dersler çok fazla yoğun geçiyor ve ben kendi başıma olunca odaklanamıyorum. Okulda daha iyi öğreniyorum (Ö.40). Öğretmenler çok hızlı ödev veriyorlar uzaktan eğitimde. Aslında bu onların değil müfredatın sorunu (Ö.11). Çok fazla zaman kaybı ve ödev var. Bıktım uzaktan eğitimden. Eskiden okulu sevmezdim şimdi kıymetini anlıyorum. Tüm günümüz uzaktan eğitimle ödevlerle geçiyor. Çok fazla ödev ve ders var. Yorucu bir şey bu uzaktan eğitim (Ö.9).

Seslerin üst üste gelip karışması: Bazen gürültü çok fazla oluyor. Derste hevesim kaçıyor (Ö.25). Sınıf ortamına bakılırsa uzaktan derse girmede sıkıntılar olabiliyor. Biri bir şekilde ya da bir aksaklıktan dolayı geç giriyor, hocanın internet bağlantısı düşüyor ya da kaliteli olmuyor yani bir şekilde ders bölünebiliyor. Benim dikkatimde kayboluyor (Ö.33). Sosyal bilgiler dersini uzaktan pekiyi anlayıp kolay kavrayamıyorum. Gürültü olması, öğretmenin uzaktan eğitimi bilmemesi, dikkatimin kolayca dağılması, internet sorunları gibi sebepler var (Ö.40). 
Yalnızılı hissi uyandırması: Arkadaşlarımla kavga etmeyi barışmayı ve gülümsemeyi unuttum (Ö.36). Yalnızlık çok kötü ve öğretmenime sarılamamak beni çok üzüyor (Ö.7). Uzaktan eğitimde kendimi çok yalnız hissediyorum ve daha çabuk yoruluyorum. Bazen bıkkınlık geliyor (Ö.28). Derslerde öğreniyorum ama biraz fazla ekran karşısında kalınca başım ağrıyor, boynum tutuluyor ve canım sıkılıyor (Ö.32). Evde uzaktan eğitim sırasında yalnızım ve etrafıma bakınca kimse olmuyor. Yalnız derse girmek çok kötü bir duygu. Bu benim derslere katılma isteğimi yok ediyor (Ö.5).

Öğretmene ulaşılmaması: Öğretmenler de hep yüz yüze eğitime alıştığından dolayı internet ortamında daha acemi olabiliyor (Ö.4). Öğretmen de sınıf ortamı olmayınca kendini garip hissediyor ve bu gariplik öğrenciye yansıyor (Ö.1). Öğretmenlerin ders işleme hevesi azaldı uzaktan eğitime geçildikten sonra. Sınıfımızda bir derste \%70-80 derse katılım varken artık o katılım \%30-40'lara düştü. Bazen de son dakikalara doğru ögrretmen tam konuyu toparlayacakken ders süresi bitmiş oluyor ve bir anda o ders ekranından ayrılmak zorunda kalıyoruz (Ö.40).

Arkadaş ilişkilerimin azalmasına: Öğretmenimle istediğim şekilde konuşamıyorum bana çok çok uzak geliyor (Ö.16). Uzaktan eğitimde her şey sahte gibi. Gerçekten olmuyormuş gibi. Film gibi. Kafamda oluyormuş gibi. Hiçbir şey inandırıcı değil. Arkadaşlarımdan uzaklaşmak çok üzücü. Uzaktan eğitimi sevmiyorum (Ö.19). Yüz yüze eğitimde teneffüse çıkıp arkadaşlarımla oynuyordum şimdi bunu yapamayınca üzülüyorum (Ö.17).

Sürekli dinleyici-izleyici olunması: Bazen gerçek olarak yakından görülmeyince anlamakta zorlanılan dersler vardır. Sosyal Bilgiler dersi ise şahsi görüşüm olarak bu derslerin arasındadır (Ö.2). Sosyal bilgiler dersinde çok güzel şeyler öğrendik kabul ediyorum ancak çok yoğun öğrendiğim bilgiler çabuk siliniyor kafamdan. (Ö.23). Sanal gezilerde müzeler ve tarihi yerleri gezdik ama gerçekten gezmedik ki bazen çok anlamsız geliyor bu uzaktan eğitim (Ö.40). Yüz yüze eğitimde kendimizi anlatıyorduk en azından şimdi ise sadece dinliyoruz (Ö.18).

Ekrana bakarak ders yapmanın yorucu olması: Özellikle sosyal bilgiler dersi için olumsuz bir yön yok, her derste olan olumsuz yönler burada da söylenebilir. Mesela beş ders yüz yüze ders gördüğümde uzaktan eğitimde gördüğümden daha az yoruluyorum. Ekran çok yoruyor (Ö.37). Uzaktan eğitimi olumsuz buluyorum. Saatlerce ekran karşısında olmak hem öğrenciler ve hem de öğretmenler için çok yorucu ve zor. Bu durum bir an evvel bitsin yüz yüze eğitim başlasın istiyorum (Ö.9). Beyaz ışıkla ders yapmak bana yaramıyor. Yoruluyorum ve başım ağrıyor. Okulda böyle olmuyorum (Ö.39). 
Öğretmenlerin günün her saatinde ders atamaları: Öğretmenler bu uzaktan eğitim işini çok abartlyorlar. Sabahtan gece yatana kadar ders olur mu? Onların canı sıkıldıkça bizi derse alıyorlar (Ö.11). Ders atamaları çok fazla zamana yayılarak yapılınca kendime ayıracak zamanım hiç kalmıyorum (Ö.23). Ne zaman oyun oynayacağım ve eğleneceğim ben, hiç bilmiyorum (Ö.32). Ders süreleri çok uzun ve saatleri çok fazla, çok yoruluyorum. Gözlerim yorulunca ışığa bakamaz hale geliyorum (Ö.16).

\subsection{3. Öğrencilerin Sosyal Bilgiler Dersi Açısından Uzaktan Eğitime Yönelik Beklentilerine İlişkin Bulgular}

İlkokul ve Ortaokul öğrencilerin Sosyal bilgiler dersi açısından nasıl bir uzaktan eğitim dersi olmasını istediklerine ilişkin görüşler aşağıdaki tablo $11^{\prime}$ 'de gösterilmiştir.

Tablo 11: Sosyal Bilgiler Dersi Açısından Uzaktan Eğitimin Nasıl Olması Gerektiğine Yönelik Öğrenci Görüşleri

\begin{tabular}{l|l|l|l|l|l}
\hline Görüşler & \multicolumn{5}{|c}{ Sınıf Düzeyi } \\
& $\mathbf{4}$ & $\mathbf{5}$ & $\mathbf{6}$ & \multicolumn{1}{c}{ T.G. } \\
\hline Yüz yüze+ uzaktan (hibrit) olmalı & 2 & 3 & 3 & 3 & 11 \\
Uzaktan canlı ders yerine kayıtlar & 2 & 2 & 3 & 3 & 11 \\
olmalı & & & & & \\
Daha çok sosyal bilgiler dersi olmalı & 2 & 3 & 3 & 3 & 11 \\
Sınıflarda öğrenci sayıları az olmalı & 2 & 2 & 3 & 3 & 10 \\
Daha fazla görsel konulmalı & 3 & 3 & 2 & 2 & 10 \\
Daha çok öğrenciler ders anlatmalı & 3 & 2 & 2 & 3 & 10 \\
Yüz yüze kameralar açık olsun & 2 & 2 & 2 & 3 & 9 \\
Daha çok test çözümü olsun & 1 & 1 & 3 & 3 & 8 \\
\hline Sınıflara Göre Toplam Görüş & 17 & 18 & 21 & 23 & 80 \\
\hline
\end{tabular}

Tablo 11 'de görüldüğü gibi, öğrenciler yüz yüze eğitim ile uzaktan eğitimi birlikte olması gerektiğini belirtmiştir (11). Öğrencilerin teknik aksaklıklardan dolayı derse giremediği zamanlarda ders kayıtlarının izlenme imkânının olması yönündeki görüşleri bulunmaktadır (11). Sınıf seviyesi arttıkça test çözümün de artmasını isteyen öğrenciler küçük sınıflara göre daha fazladır. İlkokul öğrencileri test çözümü için 1 görüş belirtirken ortaokul öğrencileri ve özellikle 7.sınıf öğrencileri 3 görüş bildirmiştir. Sosyal bilgiler dersi açısından uzaktan eğitime yönelik öğrenci görüşlerinden yapılan alıntılar şu şekildedir:

Hem yüz yüze ve hem de uzaktan olsun: İki şekilde eğitim olsa daha iyi. Derslerin özelliklerine göre biz de daha iyi yararlanırız (Ö.33). Her dersi uzaktan iyi öğrenemediğimiz gibi her dersi de yüz yüze öğrenemiyorum. İki şekliyle olsa bu başarımız arttırabilir (Ö.17). Uzaktan eğitim değil de yüz yüze eğitim olmasını istiyorum. Uzaktan eğitim de canım sıkılıyor hoca 100 
versin hiç önemi kalmıyor, yoruluyorum (Ö.22). İki sistem birbirinden çok faklı ikisi de olursa daha iyi öğrenebilirim (Ö.14). Hiç eğlenceli biz sistem değil uzaktan eğitim. Bu nedenle sosyal bilgiler dersinde gerçekten gezip görmek ve eğlenmek için yüz yüze eğitimi tercih ederim. Ancak haftada bir gün sosyal bilgiler dersi ve diğer dersler uzaktan olabilir. İkisinin birlikte olması en mantıklısı olur (Ö.13).

Uzaktan canlı ders yerine kayıtlar olsun. Temel dersler ve ödevler çok fazla ve öğrenciler seyirci gibi, hiç iyi olmuyor. Canlı yayına giremediğim de kayıtlardan yararlanmak iyi oluyor (Ö.5). Bazı okullarda kayıtlar var, biz de yok, her dersin eğitim siteleri var, bizim okullarında böyle olmasını istiyorum (Ö.12).

Daha çok sosyal bilgiler dersi olsun: Hep matematik ve fen yapıyoruz. Sosyal bilgiler dersine çalışmaya ve ilgilenmeye hiç zaman kalmıyor. Diğer ders sayıları azaltılmalı (Ö.5). Sosyal bilgiler dersin daha da çok görsellerle zenginleştirilmeli ve ders sayısı arttırılmalı. Hatta bir derste eklenmeli ve sosyal bilgiler derslerine ilgi duyanlar için sosyal bilgilerin de seçmeli dersi fazladan konulmalı (Ö.30). Sosyal bilgiler dersleri ve sanat dersleri arttırılmalı (Ö.11). Uzaktan eğitim öğlene kadar olmalı sonra resim, müzik ve diğer yetenek dersleri olmalı ve bunlar seçmeli olmalı. İstemeyen girmesin (Ö.12).

Sınıfta öğrenci sayıları azaltılmalı: Çok fazla öğrenci olunca sosyal bilgiler dersini hiç anlayamıyorum (Ö.2). Öğrenciler çok olunca derler sesli ve anlaşılmaz oluyor (Ö.22). Öğrenciler çok olmazsa uzaktan eğitim daha güzel olurdu, ses çok olunca derste anlaşılmaz oluyor (Ö.35).

Daha çok görsel konulsun: Uzaktan eğitimde kitap takibi, okuma ve sadece seyretme dersin dikkatini düşürüyor. Farklı çalışmalar yapılsa heyecanlı olsa güzel olurdu (Ö.16). Sosyal bilgiler dersini çok sevsem de bazen derste kendimi kaybolmuş gibi hissediyorum. Yoksa öğrenme de sorun yok, sosyal bilgiler dersini çok iyi öğreniyorum, dikkatim dağılıyor daha çok görsel ya da video olsa keşke (Ö.29).

Daha çok öğrenciler ders anlatsın. Hocaların derslerde söz hakkı alamayan öğrencileri eksi atmak yerine niye konuşmuyorsun diye sorup nedenini öğrenmeleri gerekiyor ama sormuyorlar, hocalar öğrencilerden çok uzaklaştılar (Ö.7). Derslerde öğrenciler konuları anlatsalar daha ilgi çekici olur. Hep seyirci olunca sıkılıyoruz. (Ö.23). Sosyal bilgiler dersinde teorik ders anlatımları yerine uygulamalı ders işlenmesi daha iyi olur. Uykumuz geliyor oturup izlemekten (Ö.11). 
Yüz yüze kameralar açık olsun: Kameraların kapalı olması benim dersten kopmamı sağlıyor. İletişim için kameralar açık olmalı (Ö.17). Kameralara alışamadım bir de kapalısına hiç alışamadım, bir uzaktan eğitimde kapalı kameralar arkasında neler dönüyor diye düşünüyorum ve herkes başka işle uğraşıyor düşüncesi beni çok rahatsız ediyor (Ö. 7). Sosyal bilgiler dersine katılım için kameraların açık olması gerekiyor kamera kapalı konuşa kişiyi dinlemekte sıkıntı çekiyorum (Ö.32).

Daha çok test çözümü olsun: Ben 7. sınıf öğrencisiyim. Konu anlatımları kayıttan olsun isterim ancak soru çözümleri canlı olmalı. Daha çok soru çözülmesi benim için çok faydalı olur (Ö.29). Konu anlatımlarından belli bir yere gelindiğinde tekrarlardan çok sıkılıyorum, soru çözümü için canlı dersler daha çok konulmalı (Ö.33). Testlerin çözümü için ayrı bir saat konulsa çok iyi olacak. İsteyen girsin bu derslere istemeyen girmesin (Ö.26).

\section{SONUÇ TARTIŞMA VE ÖNERİLER}

Sosyal bilgiler öğretmenleri, uzaktan eğitimin dijital ortamda zengin içeriklere ulaşmada kolaylık sağladığı, dikkati çektiği ve motivasyonu canlı tuttuğunu belirtmektedir. Ancak, uzaktan eğitimin öğrencilerin sosyalleşmesinde ve öğrenci-öğretmen arasında iletişimde sorunlara da Sayfa | 1669 neden olduğu da vurgulanmaktadır. Bu görüşler öğretmenlerin mesleki kıdemlerine göre incelendiğinde; 1-5 yıl mesleki kıdeme sahip sosyal bilgiler öğretmenleri uzaktan eğitimde kullanılan zengin içeriklerin zamandan tasarruf sağlamasından dolayı yararlı olduğunu ve hızlı öğrenmeyi sağladığı belirtmişlerdir. 6-10 yıllık kıdeme sahip sosyal bilgiler öğretmenleri, uzaktan eğitimde beceri ve sanat derslerinin zor yapıldığını, uygulamaya yönelik sorunlar yaşandığını; ancak diğer derslerin işleyişinin daha kolay olduğunu ifade etmişlerdir. 11 yıl ve üstü kıdeme sahip öğretmenler ise; öğrencilerin ders sayısının fazla olmasından dolayı, sağlık ve sosyalleşme açısından olumsuz sonuçlarla karşılaşabileceğini vurgulamışlardır. Sosyal bilgiler öğretmenlerin uzaktan eğitimin salgın hastalığın yayıldığı bu süreçte gerekli ve yerinde bir uygulama olduğuna ilişkin görüşlerini, Erbil ve Kocabaş (2019) tarafından yapılan araştırma sonuçları destekler niteliktedir.

Sosyal bilgiler dersi öğretmenleri uzaktan eğitime hazırlık ve uygulama sürecinde dikkat ettikleri hususlar olarak; öğretimi planlama, sınıf seviyesine uygun eğitim havuzları hazırlama ifade edilmiştir. Alt yapı hazırlıkları arasında teknolojik donanımının büyük bir kısmının öğretmenlerin bireysel çabalarıyla sağladıkları belirtilmiştir. Öğretimi planlama hazırlık aşamasında önemlidir. Mengi ve Alpdoğan (2020), tarafından yapılan çalışmada da öğretmenlerin EBA programı üzerinden 
uzaktan eğitimi planladıkları belirtilmiştir. Milli Eğitim Bakanlığının ve diğer kurumların uzaktan eğitim sürecinde öğretmen ve öğrencilerin yeterli düzeyde gerekli teknolojik donanımı sağlayamadıkları çeşitli çalışmalarda (Erbil ve Kocabaş 2019) ifade edilmiştir.

Sosyal bilgiler dersi öğretmenlerinin uzaktan eğitime yönelik olumlu görüşlerine bakıldığında; pandemi sürecinde kullanılması gerekli bir sistem olduğu, zamandan tasarruf ve öğrencilere zengin içerik sunulmasını sağladığı belirtilmiştir. Uzaktan eğitimin zaman ve mekândan bağımsız, hayat boyu sürdürülebilir, esnek, işlevsel, daha az maliyetli ve zengin içerikli olması olumlu görülen yönlerdendir. Uzaktan eğitimin evlerde olan öğrenci ve öğretmenlere rahatlık sağladığı uygulanmasının kolay olduğu için gelecekte uzaktan eğitimin daha da yaygınlaşacağını düşünülmektedir (Picciano, 2017). Sosyal bilgiler öğretimi için uzaktan eğitim zengin içeriklerin internet ortamında bulunması, teknolojilerden düşük maliyetlerle hızlı bir şekilde yararlanılması büyük bir avantaj olarak görülmektedir. Çeşitli araştırmalarda da öğretmenlerin uzaktan eğitime yönelik olumlu görüşlerinde benzer sonuçlara ulaşılmıştır: Uzaktan eğitimde internet kullanımı vakit kaybını en aza indirmesi, mekandan bağımsız olma, ders kayıtlarının izlenmesi, pandemi sürecinde ihtiyacı karşılaması, teknolojik beceri gelişimi sağlaması gibi olumlu görüşlerin bulunduğu araştırmalar Sayfa | 1670 (Özdoğan ve Berkant, 2020; Keskin ve Kaya, 2020; Fidan, 2020; Alper, 2020; Arslan ve Şumuer, 2020; Dilekçi ve Limon, 2020; Adıgüzel, 2020; Demir ve Özdaş, 2020; Kurnaz vd., 2020; Türker ve Dündar, 2020; Mengi ve Alpdoğan, 2020; Özgül vd., 2020; Ünal ve Bulunuz, 2020; Gören vd., 2020) araştırma sonuçları destekler niteliktedir.

Sosyal bilgiler öğretmenleri uzaktan eğitimle ilgili sorunlar olarak; alt yapı eksikliği (internet kesintisi), derse katılımın yeterli olmaması ve kontrol edilememesi etkileşim ve eşit diyalog eksikliği, değerlendirme yetersizliği, eğitim-öğretim süreçlerindeki tutarsızlıklar, sosyalleşmede eksiklikleri, esnek eğitimin doğru kullanılmaması, transaksiyonel uzaklık (boşluk ve yalnızlık hissi), grup çalışması yetersizlikleri, fırsat eşitsizliği belirtmiştir. Çeşitli araştırmalarda da benzer sorunlarla karşılaşılmaktadır: Paydar ve Doğan (2019)'a göre, uzaktan eğitime yönelik olumsuzlukların başında alt yapı eksikliği ve eğitim-öğretim donanımı konusunda yetersizlikler gelmektedir. Öğrencilerin sosyo-ekonomik yapılarının birbirinden farklı olması uzaktan eğitime yansıyan farklılıkları ve eşitsizlikleri de beraberinde getirmiştir. Turan ve Barış (1999)'in araştırmalarında uzaktan eğitimde gereken donanım ve alt yapı eksikliğinden doğan eğitime erişim, kaynakların verimli kullanılmaması, arz-talep dengesinin olmaması, işlevsel bir eğitim hizmetinin verilmemesi, niteliklerinin düşüklüğü eğitimde fırsat 
eşitsizliği yaratması uzaktan eğitimin olumsuz görülen yönlerindendir. Fırsat eşitsizliği, motivasyon kaybı, ölçme ve değerlendirmenin az olması, sosyalleşme yetersizliği, iletişim- etkileşim eksikliği gibi sorunlar birçok araştırmanın sonuçları arasındadır (Özdoğan ve Berkant, 2020; Alper, 2020; Arslan ve Şumuer, 2020; Dilekçi ve Limon, 2020; Adıgüzel, 2020; Demir ve Özdaş, 2020; Kurnaz vd., 2020; Türker ve Dündar, 2020; Mengi ve Alpdoğan, 2020; Özgül vd., 2020; Ünal ve Bulunuz, 2020; Gören vd., 2020).

21 yıllık ve üstü kıdemde olan öğretmen görüşlerinden, uzaktan eğitimde çeşitli sorunlar yaşadıkları ve bu sisteme daha temkinli yaklaştıkları anlaşımaktadır. Benson ve Samarawickrema (2009)'nın yaptıkları araştırmada uzaktan eğitim sisteminde hem öğrencilerin hem de öğretmenlerin uyum sorunları yaşadıkları araştırmanın bulgularıyla benzerlik göstermektedir. Sosyal bilgiler öğretmenleri uzaktan eğitim araçlarını ve altyapısını oluşturmak ve kullanmak için bireysel gayretlerle sorunları çözmeye çalıştıklarını ifade etmişlerdir. Uygulamalarda eksik kaldıkları durumlarda kendilerini yetersiz gördüklerini ve bu yetersizlikleri sebebiyle ders süresinde zaman kaybettiklerini belirtmişlerdir (Korucu ve Sezer, 2016). Alper (2020)'ın çalışmasında ise, öğretmenlerin uzaktan eğitime, teknolojiye uyum sağladıkları, benimsedikleri vurgulanmaktadır.

Sayfa | 1671

Sosyal bilgiler öğretmenleri uzaktan eğitime yönelik yaşanan sorunları aşabilmek için bazı önerilerde bulunmuşlardır. Bu öneriler; uzaktan sosyal bilgiler eğitimi müfredatı oluşturulması, dijital derslere uygun yöntem ve teknikler geliştirilmesi, online içeriklerin zenginleştirilmesi, öğretmenlerin uzaktan eğitim konusunda hizmet içi eğitim almaları, her öğretmen ve öğrenciye teknik donanım sağlanması, sınıflardaki öğrenci sayısı azaltılması şeklindedir. Öğretmenlerden alınan görüşlere göre uzaktan eğitim için hizmet içi eğitim talep etmeleri, onların bu konudaki çeşitli desteklere ihtiyaçları olduğunu gösterebilir. Yapılan çeşitli araştırmalarda da, uzaktan eğitim sürecinde öğretmenlerin eğitime intiyaçları olduğu, bilgi ve becerilerini kurumlarının ve eğitim yöneticilerinin destekleriyle geliştirmek istedikleri anlaşımaktadır (Polat, 2016; Ünal ve Bulunuz, 2020). Eğitim sisteminin yapı ve işleyiş̧inde meydana gelen bazı değişmeler öğretmenlerin hizmet içinde sürekli eğitim almaları zorunluluğu ortaya çıkarmıştır (Çelikten ve Şanal 2005). Değişim ve gelişimin sürekli ve hızlı olduğu günümüz şartlarında öğretmenlerin diğer eğitimlerde olduğu gibi profesyonel olmaları ve sürekli gelişime açık olmalarını gerekmektedir (Braxton, 2000). Çeşitli araştırmalarda çalışmayı destekler nitelikte; altyapının güçlendirilmesi, ders sayısının azaltılması, ölçme ve değerlendirmelere önem verilmesi, etkileşim arttırılması gibi önerilerde 
bulunulmuştur (Özdoğan ve Berkant, 2020; Arslan ve Şumuer, 2020; Adıgüzel, 2020; Ünal ve Bulunuz, 2020; Mengi ve Alpdoğan, 2020).

İlkokul ve ortaokul öğrencilerinin uzaktan eğitime ilişkin olumlu görüşleri; uzaktan eğitimin evden sürdürülebilmesinin büyük bir rahatlık ve kolaylık sağladığı, okula gidişin olmamasının zamandan tasarruf kazandırdığı, öğrenmenin daha hızlı olması, uzaktan eğitimin motivasyonu arttırması, sınavların daha az sayıda yapılmasını, ders kayıtlarına sonradan ulaşılarak yeniden izlenebilmesi şeklindedir. Uzaktan eğitime ilişkin öğrenci görüşlerinin alındığı araştırmalarda da benzer sonuçlar elde edilmiştir (Özdoğan ve Berkant, 2020; Gören vd., 2020).

Öğrencilerin uzaktan eğitime ilişkin olumsuz görüşlerine yönelik hususlar, ders esnasında internet kesintisi, ders esnasında öğrencilerin yalnızlık hissetmesi, ders saatlerinin fazla olması, seslerin karışması, öğretmene ulaşmada sıkıntıların oluşması, arkadaşlık ilişkilerinin azalması, ekran karşısında çoğu kez dinleyici olarak kalınması, öğretmenlerin esnek zamanı istedikleri şekilde kullanarak günün her saatini derslerle doldurmaları, oyuna, sanat, kültüre ve arkadaşlık yapmaya zamanın kalmaması olarak öne çıkmaktadır. Araştırmaya katılan sosyal bilgiler öğretmenleri ve öğrenciler uzaktan eğitim ile sosyalleşmede sıkıntılar yaşadıklarını belirtmişlerdir. Çeşitli araştırmalar bu sonucu destekler niteliktedir (Simonson vd., 2019; Özdoğan ve Berkant, 2020; Gören vd., 2020). Yapılan araştırmalara göre; öğrenciler uzaktan eğitimde iletişimetkileşim eksikliği, sosyalleşme eksikliği, donanım eksikliği, motivasyon kaybı, internet kesintileri ile karşılaşma ve fırsat eşitsizliği gibi sorunlar yaşadıklarını belirtmiştir. Transaksiyonel uzaklık sebebiyle, öğretmenler ve öğrenciler arasındaki uzaklık sadece fiziki olmayıp, duygusal bağlamda da olumsuz sonuçlar meydana getirdiği çeşitli çalışmaların bulgularında yer almaktadır (Oosterhoff vd., 2020).

Öğrencilerin uzaktan eğitime yönelik önerileri; hem yüz yüze ve hem de uzaktan eğitimin olması gerektiği, uzaktan canlı ders yerine kayıtların olması, daha çok görsel konulması, kameraların açık olması, daha çok test çözümü olması yönündedir. Sosyal bilgiler derslerinin dijital gezi, gözlem ve uygulamaya yönelik yazııımlarının artması da öneriler arasındadır. Özdoğan ve Berkant (2020) tarafından yapılan araştırmada da etkileşimin arttırılması, internet-bilgisayar imkanının sağlanması ve hibrit eğitim olması gibi öneriler araştırmayı destekler niteliktedir.

\section{ÖNERİLER}

Uzaktan eğitim sınıfları yetenek ve ilgiye göre yeniden düzenlenebilir. Sosyal bilgiler dersine diğer derslerden daha fazla ilgi duyan öğrenciler bu 
derslerin çevrim içi ve çevrim dışı eğitim havuzlarından istedikleri zamanda yararlanmaları sağlanabilir. Uzaktan eğitimin kalitesini arttırmanın bir diğer yolu da öğrencilerin sosyal medya ve herhangi bir arama motoru kullanmaması için tablet ve derslerde dikkat dağıtıcı hiçbir uygulamanın uzaktan eğitim araçlarındaki eğitim ortamında olmamasıdır. Uzaktan sosyal bilgiler eğitim paket programlarının önceden tablet ya da bilgisayarlara yüklenmiş eğitim donanımının olması ve derslerin bu programlara göre işlenmesinin öğrenci dikkatini daha az dağıtacağını ve eğitimin daha kaliteli hale getireceği düşünülebilir. Uzaktan eğitimde yapılan tüm eğitim hizmetlerine öğrencilerin çevrimiçi olmadıkları zamanda da ulaşmalarına imkân sağlayacak kayıtların yaygınlaşmasının eğitime erişim eşitsizliğini ortadan kaldırması açısından yararlı olabilir. Araştırmaya katılan öğretmenlerin ve bağlı bulundukları kurumların uzaktan eğitimi yönetme ve doğru kullanma konusunda programlar düzenleyerek öğretmenleri ve öğrencileri bu programlarla seminer ve hizmet içi eğitme almaları uzaktan eğitimin önceliklerindendir. Bunun yanında çeşitli sebeplerle uzaktan eğitime erişim sağlayamayan öğrencilerin kullanılacak donanım ve altyapının devlet tarafından öğretmen ve öğrencilere ücretsiz sağlanması öneriler arasında yer almaktadır.

\section{KAYNAKÇA}

Adıgüzel, A. (2020). Salgın Sürecinde Uzaktan Eğitim ve Öğrenci Başarısını Değerlendirmeye İlişkin Öğretmen Görüşleri. Millî Eğitim Dergisi 49(1), 253271.

Alper, A. (2020). Pandemi Sürecinde K-12 Düzeyinde Uzaktan Eğitim: Durum Çalışması. Milli Eğitim Dergisi 49(1), 45-67.

Altunışık, R., Coşkun, R., Bayraktaroğlu, S. \& Yıldırım, E. (2010). Sosyal Bilimlerde Araştırma Yöntemleri: SPSS Uygulamalı. 6. Baskı. Sakarya: Sakarya Kitabevi.

Arslan, Y. \& Şumuer, E. (2020). Covid-19 Döneminde Sanal Sınıflarda Öğretmenlerin Karşılaştıkları Sınıf Yönetimi Sorunları. Millî Eğitim Dergisi 49(1), 201-230,

Arslan, A. (2020). Öğretmen Adayları Perspektifinden Pandemi Öncesi ve Sonrası Öğrencilere Kazandırılması Gereken 21. Yüzyıl Becerilerinin Belirlenmesi. Millî Eğitim Dergisi 49(1), 553-571.

Benson, R. \& Samarawickrema, G. (2009). Addressing the Context of ELearning: Using Transactional Distance Theory to Inform Design. Distance Education 30(1), 5-21. 
Bozkurt, A. (2017). Açık ve Uzaktan Öğrenme Kapsamında Dijital Bölünme. Açık ve Uzaktan Öğrenmede Bireysel Farklılıklar. (Ed.). Volkan Yüzer. Anadolu Üniversitesi Açıköğretim Fakültesi Yayını, s. 23-42, Eskişehir.

Braxton, S.N. (2000). Empirical Comparison of Technical and Non-Technical Distance Education Courses to Derive a Refined Transactional Distance Theory as the Framework for a Utilization-Focused Evaluation Tool. Unpublished Dissertation. George Washington University.

Creswell, J. W. (2013). Nitel Araştırma Yöntemleri: Beş Yaklaşıma Göre Nitel Araştırma ve Araştırma Deseni. (Çev. Ed.). Bütün, M. \& Demir, S. B. Ankara: Siyasal Kitabevi.

Çallı, İ., İşman, A. \& Torkul, O. (2002). Sakarya Üniversitesi'nde Uzaktan Eğitimin Dünü, Bugünü ve Geleceği. Sakarya Üniversitesi Eğitim Bilimleri Dergisi 0(3), 1-8.

Çelikten, M. \& Şanal, M, (2005). Öğretmenlik Mesleği ve Özellikleri. Erciyes Üniversitesi Sosyal Bilimler Enstitüsü Dergisi 19, 207-237

Çınar, M., Tüzün, H., Yıldırım, D., Akıncı, A., Kalaycı, E., Bilgiç, H. \& Yüksel, Y. (2011). Uzaktan Eğitimde Kullanılan Eşzamanı Sanal Sınıf Araçlarının Karşılaştırılması. XIII Akademik Bilişim Konferansı Bildirileri. İnönü Üniversitesi, Malatya.

Çoruk, H. \& Çakır, R. (2017). Çoklu Ortam Kullanımının İlkokul Öğrencilerinin Akademik Başarılarına ve Kaygılarına Etkisi. Turkish Journal of Computer and Mathematics Education (TURCOMAT) 8(1), 1-27.

Demir, F. \& Özdaş, F. (2020). Covıd-19 Sürecindeki Uzaktan Eğitime İlişkin Öğretmen Görüşlerinin İncelenmesi. Milli Eğitim Dergisi 49(1), 273-292.

Dewey, J. \& Bentley, A. F. (1949). Knowing and Known. Beacon Pres. Boston, USA.

Dilekçi, Ü. \& Limon, İ. (2020). Covid-19 Salgını Bağlamında Öğretmenlerin Algıladıkları "Aşırı İletişim Yükü" Düzeylerinin İncelenmesi. Millî Eğitim Dergisi 49(1), 231-252.

Duman, S. N. (2020). Salgın Döneminde Gerçekleştirilen Uzaktan Eğitim Sürecinin Değerlendirilmesi. Millî Eğitim Dergisi 49(1). 95-112.

Emre, Y. (2002). Kitle İletişim Araçları ve WWW Teknolojilerinin Uzaktan Eğitim Uygulamalarında Kullanılması. Açık ve Uzaktan Eğitim Sempozyumu. 23-25 Mayıs 2002, Anadolu Üniversitesi: Eskişehir.

Erbil, D. G. \& Kocabaş, A. (2019). Sınıf Öğretmenlerinin Eğitimde Teknoloji Kullanımı, Tersine Çevrilmiş Sınıf ve İşbirlikli Öğrenme Hakkındaki Görüşleri. İlköğretim Online 18(1), 31-51. 
Erol, M. \& Erol, A. (2020). Koronavirüs Pandemisi Sürecinde Ebeveynleri Gözünden İlkokul Öğrencileri. Millî Eğitim Dergisi 49(1), 529-551.

Evans, T. D. \& Nation, D. E. (1989). Dialogue in Practice, Research and Theory in Distance Education. Open Learning 4(2), 37-42.

Fidan, M. (2020). COVİD-19 Belirsizliğinde Eğitim: İlkokulda Zorunlu Uzaktan Eğitime İlişkin Öğretmen Görüşleri. Uşak Üniversitesi Eğitim Araştırmaları Dergisi 6(2), 24-43.

Fourie, I. (2001). The Use of CAI for Distance Teaching in the Formulation of Search Strategies. Library Trends 50(1), 110-129.

Garrison, R. (2000). Theoretical Challenges for Distance Education in the 21st Century: A Shift From Structural to Transactional Issues. International Review of Research in Open and Distance Learning 1(1), 1-17.

Gorsky, P., Caspi, A. \& Smidt, S. (2007). Use of Instructional Dialogue by University Students in a Difficult Distance Education Physics Course. Journal of Distance Education 21(3), 1-22.

Gökdaş, Y. \& Kayri, Ö. (2005). E-Öğrenme ve Türkiye Açısından Sorunlar, Çözüm Önerileri. Van Yüzüncü Yıl Üniversitesi Eğitim Fakültesi Dergisi 2(2), 1-20.

Gören, S. Ç., Gök, F. S., Yalçın, M. T., Göregen, F. \& Çalışkan, M. (2020).

Küresel Salgın Sürecinde Uzaktan Eğitimin Değerlendirilmesi: Ankara Örneği. Millî Eğitim Dergisi 49(1), 69-94.

Gülbahar, Y. \& Guven, I. (2008). A Survey on ICT Usage and the Perceptions of Social Studies Teachers in Turkey. Educational Technology \& Society 11(3), 37-51.

Gürel, D. \& Er, H. (2020). Sosyal Bilgiler Öğretmen Adaylarına Göre Küresel Salgınlar Karşısında Güç Aldığımız Değerler: Covid-19 Örneği. Millî Eğitim Dergisi 49(1), 573-596.

Horzum, M. B. (2010). Uzaktan Eğitimde Uzaklığın Boyutları ve Tasarımı: Coğrafi Uzaklığa Karşın Transaksiyonel (Psikolojik ve İletişimsel) Uzaklığın Azaltılması. Sakarya Üniversitesi Eğitim Fakültesi Dergisi 20, 95-118.

İnan, S. (2010). Duvarsız Sınıflara Doğru mu? Çevrimiçi, Eklemli Eğitim Üzerine. Pamukkale Üniversitesi Eğitim Fakültesi Dergisi 28, 227.

İnci Kuzu, Ç. (2020). Covid-19 Pandemisi Sürecinde Uygulanan İlkokul Uzaktan Eğitim Programı (Eba Tv) ile İIgili Veli Görüşleri. Millî Eğitim Dergisi 49(1), 505-527.

İşman, A., (2011). Uzaktan Eğitim. 4. Baskı. Ankara: PegemA Yayıncılık. 
Karaman, K \& Akgül, İ. (2015). İlkokul Öğrencileri İçin Web Tabanlı Değerler Eğitimi Uygulaması. Uşak Üniversitesi Sosyal Bilimler Dergisi 8(3), 87-100.

Karasar, Ş. (2004). Eğitimde Yeni İletişim Teknolojileri - Internet ve Sanal Yüksek Eğitim. The Turkish Online Journal of Educational Technology TOJET 3(4), 117-125.

Karataş, S., Üstündağ, M. T. \& Güneş, E. (2009). Parmaklar Klavyede, Peki Ya Zihinler Nerede? E- öğrenmede Etkileşim. 9.th International Educational Technology Conference (IETC2009), Hacettepe Üniversitesi, Ankara, 6-8 Mayıs 2009.

Kavrat, B. (2013). Çevrimiçi Uzaktan Eğitimde Öğretici Yeterliklerinin Belirlenmesi. (Yayınlanmamış Yüksek Lisans Tezi). Fırat Üniversitesi. Eğitim Bilimleri Enstitüsü, Elazığ.

Kaya, Z. (2002). Uzaktan Eğitim. 1. Baskı, Ankara: PegemA Yayıncılık.

Keleş, H. N., Atay, D. \& Karanfil, F. (2020). Covid 19 Pandemi Sürecinde Okul Müdürlerinin Öğretim Liderliği Davranışları. Millî Eğitim Dergisi 49(1), 155-174.

Keskin, M. \& Özer Kaya, D. (2020). Covıd-19 Sürecinde Öğrencilerin Web Tabanlı Uzaktan Eğitime Yönelik Geri Bildirimlerinin Değerlendirilmesi. İzmir Sayfa | 1676 Katip Çelebi Üniversitesi Sağlık Bilimleri Fakültesi Dergisi 5(2), 59-67.

Kırık, A. (2016). Uzaktan Eğitimin Tarihsel Gelişimi ve Türkiye'deki Durumu. Marmara İletişim Dergisi 0(21), 73-94.

Korucu, A. T. \& Sezer, C. (2016). Web 2.0 Teknolojilerini Kullanma Sıklığının Ders Başarısı Üzerindeki Etkisine Yönelik Öğretmen Görüşleri. Eğitim ve Öğretim Araştırmaları Dergisi 5(2), 379-394.

Kurnaz, A., Kaynar H., Şentürk Barışık, C. \& Doğrukök, B. (2020) Öğretmenlerin Uzaktan Eğitime İliş̧kin Görüşleri. Millî Eğitim Dergisi 49(1), 293-322.

Mengi, A. \& Alpdoğan, Y. (2020). Covid-19 Salgını Sürecinde Özel Eğitim Öğrencilerinin Uzaktan Eğitim Süreçlerine İlişkin Öğretmen Görüşlerinin İncelenmesi. Millî Eğitim Dergisi 49(1), 413-437.

Miles, M. B. \& Huberman, A. M. (1994). Qualitative Data Analysis: An Expanded Sourcebook. (2nd ed.). Thousand Oaks, California: SAGE.

Milli Eğitim Bakanlığı (MEB). (2018). İlköğretim Sosyal Bilgiler Dersi 4-5. Sınıflar Öğretim Programı, Ankara.

Moore, M. G. (1993). Theoretical Principle of Distance Education. Theory of Transactional Distance. In D. Keegan (Ed.), (s. 22-38), London: Routledge. 
Moore, M. G. \& Kearsley, G. (2011). Distance Education: A Systems View of Online Learning. Cengage Learning.

Odabaşı, H. (2003). İnternet Tabanlı Uzaktan Eğitim ve Bilgi ve Belge Yönetimi Bölümleri. Türk Kütüphaneciliği 17(1), 22-36. 1.

Oosterhoff, B., Palmer, C. A., Wilson, J., \& Shook, N. (2020). Adolescents' otivations to Engage in Social Distancing During the COVID-19 Pandemic: Associations with Mentaland Social Health. Journal of Adolescent Health, 67(2), 179-185.

Özdil, İ. (1986). Uzaktan Öğretiminin Evrensel Çerçevesi ve Türk Eğitim Sisteminde Uzaktan Öğretimin Yeri. Eskişehir: Anadolu Üniversitesi Yayınları.

Özdoğan, A. Ç. \& Berkant, H. G. (2020). Covid-19 Pandemi Dönemindeki Uzaktan Eğitime İlişkin Paydaş Görüşleri. Millî Eğitim Dergisi 49(1), 13-43. Özgül, E., Ceran, D. \& Yıldız, D. (2020). Uzaktan Eğitimle Yapılan Türkçe Dersinin Öğretmen Görüşlerine Göre Değerlendirilmesi. Millî Eğitim Dergisi 49(1), 395-412.

Parmaksız, R. \& Sıcak, A. (2015). Uzaktan Hizmetiçi Eğitime İlişkin Öğretmen Görüşleri. Uşak Üniversitesi Sosyal Bilimler Dergisi 8(4), 187 212.

Patton, M. (2014). Qualitative Research \& Evaluation Methods. SAGE Publications,Inc.theory. Quarterly Review of Distance Education 6(1), 1-11. Paydar, S. \& Doğan, A. (2019). Öğretmen Adaylarının Açık ve Uzaktan Öğrenme Ortamlarına Yönelik Görüşleri. Eğitim ve Teknoloji 1(2), 154-162. Picciano, A. G. (2017). Theories and Frameworks for Online Education: Seeking an Integratedmodel. Online Learning 21(3), 166-190.

Polat, H. (2016). Çevrimiçi Öğrenme Ortamlarında Sınıf yönetiminin Çeşitli Değişkenler Açısından İncelenmesi. (Yayınlanmamış Doktora Tezi). Fırat Üniversitesi Eğitim Bilimler Enstitüsü, Elazığ.

Saykılı, A. (2019). Etkileşim Eşdeğerliği Kuramı: Alanyazındaki Araştırmalar ve Öneriler. Açıköğretim Uygulamaları ve Araştırmaları Dergisi 5(4), 92104.

Simonson, M., Zvacek, S. M., \& Smaldino, S. (2019). Teaching and Learning at a Distance: Foundations of Distance Education 7th Edition. IAP.

Thurmond, V. A. \& Wambach, K. (2004). Understanding Interactions in Distance Education: A Review of the Literatüre. Journal of Instructional Technology and Distance Learning 1, 9-33. 
Turan, S. (2020). Covid-19 Sürecinde Okul Müdürlerinin Teknolojik Liderliği. Millî Eğitim Dergisi 49(1), 175-199.

Turan, M. \& Gürkan B. (1999). Uzaktan Eğitim Sistemi. Birinci Uzaktan Eğitim Sempozyumu, 15-16 Kasım 1999 içinde (153-158). Ankara: Kara Kuvvetleri Eğitim ve Doktrin Komutanlığı.

Türker, A. \& Dündar, E. (2020). Covid-19 Pandemi Sürecinde Eğitim Bilişim Ağı (Eba) Üzerinden Yürütülen Uzaktan Eğitimlerle İlgili Lise Öğretmenlerinin Görüşleri. Millî Eğitim Dergisi 49(1), 323-342.

Türker, H. \& Yaylak, E. (2011). İlköğretim Sosyal Bilgiler Öğretiminde İnternet Tabanlı Öğretim Yönteminin Ders Başarısına Etkisi. Buca Eğitim Fakültesi Dergisi 29, 153-168.

Ünal, M. \& Bulunuz, N. (2020). Covid-19 Salgını Dönemi Uzaktan Eğitim Çalışmaları ve Sonraki Süreçle İlgili Fen Bilimleri Öğretmenlerinin Görüş ve Önerileri. Millî Eğitim Dergisi 49(1), 343-369.

Walcott, H. F. (1994). Transforming Qualitative Data: Description, Analysis and Interpretation. London: SAGE Publications.

Yalın, H. G. (2008). İnternet Temelli Eğitim, Ankara: Nobel Yayın Dağıtım. Yamamoto, G. T. \& Altun, D. (2020). Coronavirüs ve Çevrimiçi (Online) Eğitimin Önlenemeyen Yükselişi. Üniversite Araştırmaları Dergisi 3(1), 2534.

Yaylak, E. \& İnan, S. (2018). Sosyal Bilgiler Öğretmenlerinin Eğitimde Sosyal Medyanın Kullanılmasına Yönelik Görüşlerinin İncelenmesi. Türkiye Bilimsel Araştırma Dergisi 3(1), 1-32.

Yenal, A. Ç. (2009). Uzaktan Eğitim. (Yayınlanmamış Yüksek Lisans Tezi). Yeditepe Üniversitesi. Sosyal Bilimler Enstitüsü, İstanbul.

Yıldırım, A. \& Şimşek, H. (2011). Sosyal Bilimlerde Araştırma Yöntemleri. Ankara: Seçkin Yayıncılık.

Yılmaz, E., Güner, B., Mutlu, H. \& Arın Yılmaz, D. (2020). Farklı Öğrenim Kademelerindeki Öğrencilere Verilen Uzaktan Eğitim Hizmetinin Veli Görüşlerine Göre Değerlendirilmesi. Millî Eğitim Dergisi 49(1), 477-503.

Zhong, R. (2020). The Coronavirus Exposes Education's Digital Divide. The New York Times. Erişim Adresi: https://www.nytimes.com/2020/03/17/technology/china-schoolscoronavirus.html

GENİŞLETÍLMİş ÖZET: Covid-19 salgını nedeniyle 2020-2021 öğretim yılında, eğitim kurumlarının uzaktan eğitime geçilmesiyle; yüz yüze eğitim ile uzaktan eğitim arasında karşılaştırma yapılmaya başlanmıştır. Bu karşılaştırmaya göre, 
klasik olarak yüz yüze eğitimin bir okul binasına bağlı kalınarak, belli zaman aralıklarında, toplu olarak yapılmasının ne denli gerekli olduğu; öğrencilerin sosyalleşme intiyaçlarının ne denli karşılayıp karşılaştırmadığı, sağlık sorunlara sebep olup olmadığı, uzaktan eğitimle nasıl bir nesil yetiştirileceği hususunda tartışmaları da beraberinde getirmiştir. Araştırmanın amacı, sosyal bilgiler öğretmenleri ve ilkokul-ortaokul öğrencilerinin uzaktan eğitim sürecine ilişkin görüşlerini belirlemektir. Uzaktan eğitime yönelik olumlu ve olumsuz görüşler ele alınmış, yaşanan olumsuzluklara yönelik çözüm yolları tespit edilmeye çalışıımışıır. $\mathrm{Bu}$ araştırmada nitel araştırma deseninden olgu bilim (fenomenoloji) deseni kullanılmışır. Araştırmanın çalışma grubunu, farklı okullarda görev yapmakta olan 40 sosyal bilgiler öğretmeni ve sosyal bilgiler dersi alan $4-7$. Sınıf seviyesinde öğrenim gören olan 40 öğrenci oluşturmaktadır. Verilerin toplanmasında yarı yapılandırılmış görüşme formundan yararlanılmıştır. Araştırma verileri betimsel analiz tekniği ile çözümlenmiştir. Bu araştırmada görüşme formlarından doğrudan alıntılar yapılmış ve okuyucuya betimsel bir yaklaşımla, belirlenen temalar ve temalar arası ilişkilerle ortaya konulmaya çalışıımıştır. Araştırma bulgularına göre, öğretmenlerin uzaktan eğitime ilişkin olumlu görüşlerinde öne çıkanlar; uzaktan eğitimin faydalı, zengin içerikli, ilgi uyandıran, öğrenmeyi hızlandıran etkili bir sistem olduğudur. Zengin içeriklerin internet ortamında bulunması, teknolojilerden düşük maliyetlerle hızlı bir şekilde yararlanılması, ilgi çekici eğitim havuzlarına ulaşılması, slaytlar, sunumlar, animasyonlar ve videolar sağlaması açısından büyük kolaylıklar sunması olarak belirtilmiştir. Sosyal bilgiler öğretmenleri uzaktan Sayfa| 1679 eğitimle ilgili sorunları alt yapı eksikliği, derse katılım kontrolsüzlüğü, etkileşim ve eşit diyalog eksikliği, değerlendirme yetersizliği, eğitim öğretim süreçlerindeki tutarsızlıklar, sosyalleşmede eksiklikleri, esnek eğitimin doğru kullanılmaması, transaksiyonel uzaklık (boşluk ve yalnızlık hissi), grup çalışması yetersizlikleri olarak görmektedirler. Öğrencilerin sosyo-ekonomik yapılarının birbirinden farklı olması alt yapı eksikliğini eğitim-öğretim donanımı konusunda yetersizlikler olarak ifade etmişlerdir. Bu durum uzaktan eğitime yansıyan farklııkları ve eşitsizlikleri de beraberinde getirmiştir. Ancak salgın hastalığın yayıldığı bu süreçte uzaktan eğitimin gerekli ve yerinde bir uygulama olduğu görüşleri de belirlenmiştir. Sosyal bilgiler dersi öğretmenlerinin uzaktan eğitimde hazırlık ve uygulama sürecinde dikkat ettikleri hususlara ilişkin görüşler arasında alt yapı temini ve sınıf seviyesine uygun eğitim havuzları hazırladıklarını, önceden bu çalışmalar zaman harcadıkları anlaşılmaktadır. Alt yapı hazırlıkları arasında teknolojik donanımının büyük bir kısmının öğretmenlerin bireysel çabalarıyla sağladıkları, milli eğitim bakanlığının ve diğer kurumların uzaktan eğitim sürecinde öğretmen ve öğrencilerin yeterli düzeyde gerekli teknolojik donanımı sağlayamadıkları ifade etmişlerdir. Sosyal bilgiler öğretmenleri uzaktan eğitime yönelik yaşanan sorunları aşabilmek için bazı önerilerinde bulunmuştur. Uzaktan sosyal bilgiler eğitimin bir müfredatı olmalı; dijital derslere uygun yöntem ve teknikler geliştirilmeli; beceri ağırlıklı sosyal bilgiler dersi olmalı, içerikler zenginleştirilmeli tüm öğretmenler eşit bir şekilde kullanabilmeli, öğretmenler hizmet içi eğitimlere alınmalı, her öğretmen ve öğrenciye teknik donanım sağlanmalı, sınıflardaki öğrenci sayısı azaltılmalı olarak 
öne çıkmaktadır. Ders süreleri azaltılması için hem öğrenci hem öğretmen hem de kurum olarak donanımlı olunması birincil önem arz eden hususlardandır. Değişim ve gelişimin sürekli ve hızlı olduğu günümüz şartlarında öğretmenlerin diğer eğitimlerde olduğu gibi profesyonel olmaları ve sürekli gelişime açık olmalarını gerekmektedir. Öğretmenlerin eğitimde kullanacakları teknolojik bilgileri ve zengin içerikleri yaratma bilgi ve becerilerine sahip olması, profesyonel olmaları büyük önem taşımaktadır. Öğrencilerin uzaktan eğitime ilişkin olumlu görüşleri; uzaktan eğitimin, sabah erkenden kalkmak zorunda olmaması ve eğitimin evden sürdürülebilmesinin büyük bir rahatlık ve kolaylık sağladığını, okula gidişin olmamasının öğrencilere giderleri azaltarak maliyetlerden ve zamandan tasarruf kazandırdığını, öğrenmenin daha hızlı olması, uzaktan eğitimin motivasyonu arttırması, sınavların daha az sayıda yapılmasını, ders kayıtlarına sonradan ulaşılarak yeniden izlenebilmesi yönünde görüş belirtmişlerdir. Öğrencilerin uzaktan eğitime ilişkin olumsuz görüşler, ders esnasında internet kesintisi, öğrencilerin yalnızlık hissetmesi, ders saatlerinin fazla olması, seslerin karışması, öğretmene ulaşmada sıkıntıların oluşması, arkadaşlık ilişkilerinin azalması, ekran karşısında çoğu kez dinleyici olarak kalınması öğretmenlerin esnek zamanı istedikleri şekilde kullanarak günün her saatini derslerle doldurmaları, oyuna, sanata, kültüre ve arkadaşıı yapmaya zamanın kalmaması olarak öne çıkmaktadır. Öğrencilerin uzaktan eğitime yönelik önerilerine bakıldığında, hem yüz yüze ve hem de uzaktan eğitimin olması gerektiği, uzaktan canlı ders yerine kayıtların konulması, daha çok görsel içermesi, kameraların açık olması, daha çok Sayfa | 1680 test çözümü olması, etkileşimli çevrimiçi eğitimsel oyunların olması yönündedir. Sosyal bilgiler derslerinin dijital gezi, gözlem ve uygulamaya yönelik yazılımlarının artması da öneriler arasındadır. Öğretmenlerin ve bağlı bulundukları kurumların uzaktan eğitimi yönetme ve doğru kullanma konusunda programlar düzenleyerek öğretmenleri ve öğrencileri bu programlarla seminer ve hizmet içi eğitme almaları uzaktan eğitimin önceliklerindendir. Bunun yanında çeşitli sebeplerle uzaktan eğitime erişim sağlayamayan öğrencilerin kullanılacak donanım ve altyapının öğretmen ve öğrencilere ücretsiz sağlanması öneriler arasında yer almaktadır.

EXTENTED ABSTRACT: Due to the Covid-19 pandemic, a comparison between face-to-face education and distance learning has begun with the transition of educational institutions to distance education in the academic year of $2020-2021$. With this comparison, some discussions have appeared such as how necessary is to carry out a face-to-face education in a school building at certain times with regular intervals and collectively, how much socialization needs of the students are met, whether these situations cause health problems and how to raise a generation with distance education. The aim of this research is to pass the reviews of social studies teachers and elementary school students about the distance education. Positive and negative approaches on distance education have been discussed, and some solutions have been tried to be determined for the unfavourable conditions. In this study, phenomenology method of form of qualitative research has been used. The study group of the research consists of 40 social studies teachers working in different schools and 40 students having social studies class at $4^{\text {th }}$ and 
$7^{\text {th }}$ grades. During data collection, the semi-structured interview format has been used. The interview forms were directly quoted in the preparation of this research and it was aimed to pass the determined themes and the connections between these themes with a descriptive approach to the reader. According to the outcomes of this research, the prominent findings in positive opinions of the teachers regarding the distance learning show that distance education is an effective system that it is beneficial, rich in content, arousing interest and accelerating learning. It is emphasized that it offers great convenience in terms of finding rich content on the internet, using technologies quickly at low cost, accessing interesting information pools, providing slide shows, presentations, animations and videos. Social studies teachers see the problems related to distance education as lack of technical infrastructure, lack of control of class participation, lack of interaction and equal dialogue, inadequacy of evaluation, inconsistencies between education and training processes, deficiencies in socialization, improper use of flexible education, transactional distance (feeling of emptiness and loneliness) and group work. They have pointed out the various socio-economic backgrounds of the students and insufficient technical infrastructure and have categorized them as the inadequacies in education and training equipment. This situation has uncovered the differences and inequalities reflected within distance education. However, it has also been supported that distance education is a necessary and appropriate procedure during this period of the pandemic. Among the opinions on the issues that social studies teachers have paid attention to during the preparation and Sayfa | 1681 implementation process of distance education, it is understood that they have prepared technical infrastructure and information pools according to the levels of grades and spent time on these studies beforehand. It has been stated that among the infrastructure preparations, most of the necessary technological equipment has been provided by the individual efforts of the teachers, and the Ministry of Education and other relevant institutions could not provide sufficient technological equipment neither for teachers nor for students during the distance education process. Social studies teachers have made some suggestions to overcome the troubles experienced during the distance education period. The outstanding ones are distance social studies education must have a curriculum, methods and techniques suitable for digital lessons should be improved, there should be a skillbased social studies class, the contents should be enriched and each teacher should be able to use these contents equally, teachers should be given in-service training, technical equipment should be provided to each teacher and student, and the number of the students in a class should be limited. It is of primary significance to be equipped as a student, as a teacher and as an institution in order to shorten the duration of the lessons. In present conditions, where change and development are constant and rapid, teachers should also be professional and open to continuous progress as in other trainings. It is crucial for teachers to have the knowledge and skills to create technological information and rich the contents so that they can use in education, and to be professional. Positive opinions passed by the students about distance education are distance learning removes the necessity 
of getting up early in the morning, it provides great comfort and convenience to continue education from home, it saves costs and time since they do not go to school, the learning process becomes faster and it increases the motivation, the exams are held less frequent, the course registration can be accessed later and reviewed more than once. Most mentioned negative opinions of the students regarding distance education are a drop in internet connection during a class, feeling of loneliness, the long hours of the lessons, crosstalk, having difficulty while addressing to the teacher, the decline in friendship relations, the fact that they remain mostly as listeners in front of the screen, the teachers fill every hour of the day with lessons by using the flexible time as they prefer, lack of time for games, art, culture and friendship. Considering the suggestions of the students for distance education, it is observed that both face-to-face and distance learning should be provided; recordings should be established instead of remote live lessons, more images should be contained, cameras should be turned on, there should be more test practising and there should be online interactive educational games. It is also among the suggestions to increase the software for digital travelling, observation and practice in social studies classes. It is one of the essential priorities of distance education that teachers and their institutions should arrange some schedules on the management and correct use of distance education, and teachers and students must attend the relevant seminars and inservice training within the frame of these schedules. In addition, it is among the suggestions that the hardware and technical infrastructure prepared for the use of Sayfa | 1682 the students who cannot attend in distance educations for various reasons should be provided for free of charge to teachers and students. 